\title{
PAMIĘĆ O BITWIE POD WARNĄ W POLSKICH ŹRÓDŁACH HISTORIOGRAFICZNYCH DO KOŃCA XVI WIEKU
}

\author{
Anna Obara-Pawłowska \\ (i) http://orcid.org/0000-0002-5507-4336 \\ Uniwersytet Marii Curie-Skłodowskiej w Lublinie
}

\author{
ABSTRACT \\ REMEMBRANCE OF THE BATTLE OF VARNA IN POLISH \\ HISTORIOGRAPHIC SOURCES UNTIL THE END \\ OF THE $16^{\mathrm{TH}}$ CENTURY
}

The aim of this article is to trace the means of presenting the Battle of Varna in the Polish historiographic sources until the end of the $16^{\text {th }}$ century. Particular attention was given to such narrative elements as: issue of oath-breaking by the Christian side, information on Poles participating in the battle, formation of king Władysław's remembrance or establishment of the Jagiellonian Dynasty as the defender of Christendom (which was associated with the conviction of Poland's unique role in Europe as the Bulwark of Christendom). The article also indicates functions which the recollection of the memory of the Battle of Varna could have played throughout the period of more than a hundred years, particularly in the context of cultural memory.

Keywords: Battle of Varna, Władysław of Varna, chronicles, $15^{\text {th }}-16^{\text {th }}$ century, historical writing.

Słowa kluczowe: bitwa pod Warną, Władysław Warneńczyk, kroniki, XV-XVI stulecie, piśmiennictwo historyczne.

Bitwa pod Warną od wielu lat pozostaje jednym z szerzej komentowanych i analizowanych wydarzeń w polskiej historiografii, czego dowodem są liczne publikacje naukowe ${ }^{1}$,

${ }^{1}$ W tym miejscu nie sposób prześledzić wyczerpująco całej literatury przedmiotu. Warto odwołać się do bogatych zestawień bibliograficznych najnowszych prac traktujących o tym zagadnieniu, np.: M. Bielski, Władysław Warneńczyk na Bałkanach (1443-1444). Dwie wyprawy, Toruń 2009; A. Foryt, 1444. Krucjata polskiego króla, Kraków 2019. Nie można również zapominać o tomach czasopism: „Zeszyty Naukowe Uniwersytetu Jagiellońskiego. Prace Historyczne” (Świat chrześcijański i Turcy osmańscy $w$ dobie bitwy pod Warna: poktosie sesji zorganizowanej przez Instytut Historii Uniwersytetu Jagiellońskiego w Krakowie w dniach 14-15 listopada 1994 r. w 550-lecie bitwy pod Warna, red. D. Quirini-Popławska, „Zeszyty Naukowe Uniwersytetu Jagiellońskiego. Prace Historyczne”

Adres do korespondencji: anna.obara-pawlowska@mail.umcs.pl 
popularnonaukowe czy publicystyczne ${ }^{2}$. Wydarzenia, jakie rozegrały się na polach warneńskich w 1444 roku, oraz związana z tym miejscem tragiczna postać króla Władysława Jagiellończyka wciąż, po niemalże 600 latach, prowokują do stawiania nowych hipotez badawczych oraz reinterpretowania znanych źródeł. Przy okazji nasuwa się pytanie, czy zainteresowanie tym epizodem, luźno związanym z dziejami ojczystymi, było znaczące dla Polaków zajmujących się historią w ciągu pierwszych kilkunastu dekad po 1444 roku. Celem niniejszego artykułu jest prześledzenie, jak pamięć o bitwie pod Warną była kształtowana na kartach polskich źródeł historiograficznych w okresie od drugiej połowy XV do końca XVI wieku³. W tekście nie będę wskazywać różnic zachodzących między sferą faktograficzną przedstawioną przez dziejopisów a ustaleniami poczynionymi przez współczesną historiografię. Rozważania zostaną oparte przede wszystkim na analizie stosownych fragmentów polskich kronik czy traktatów historycznych ${ }^{4}$. Skupienie uwagi na tego rodzaju źródłach jest zasadne z kilku powodów. Sami autorzy, wyjaśniając motywy, jakimi kierowali się w swej pracy, często odwoływali się do idei wskrzeszenia bądź utrwalenia na piśmie pamięci o dawnych czynach i ich bohaterach ${ }^{5}$. Utwory historiograficzne kształtowały pamięć o minionych wydarzeniach, realizując przy tym cel moralizatorsko-dydaktyczny zgodnie ze starożytną maksymą głoszącą, że historia jest nauczycielką życia. W założeniu wielu autorów dzieła te odgrywały niepoślednią rolę w wychowywaniu przyszłych pokoleń, nowych przedstawicieli elit polityczno-intelektualnych, odpowiedzialnych za losy Królestwa Polskiego i jego mieszkańców ${ }^{6}$. Odpowiednio kreowany obraz przeszłości, eksponowanie pewnych wątków, interpretacja zachowań bohaterów miały na celu ukształtowanie odbiorcy. $Z$ zadaniami stawianymi w owym czasie przed piśmiennictwem historiograficznym wiąże się także zagadnienie realizacji potrzeb państwa, większych grup ludzkich (narodu) czy domu panującego. Kroniki i inne utwory traktujące o przeszłości mogły spełniać ważną funkcję

1995, nr 119) oraz „Balcanica Posnaniensia. Acta et studia” (Warna 1444. Rzeczywistość i tradycja, „Balcanica Posnaniensia. Acta et studia" 1997, t. 8) w całości poświęconych rozważaniom o bitwie pod Warną.

${ }^{2}$ S. Sroka, Stawa, chwata i plotka. Władystaw Warneńczyk jako król Węgier, „Przegląd Nauk Historycznych" 2016, r. 15, nr 2, s. 104.

${ }^{3}$ Autorka niniejszego artykułu nie rości sobie pretensji do wyczerpania tematu. Będzie to możliwe dopiero po przeanalizowaniu motywu warneńskiego w polskich źródłach narracyjnych oraz rozszerzeniu horyzontu czasowego rozważań.

${ }^{4}$ Cechą staropolskiej epiki historycznej była przewaga kronik (L. Szczerbicka-Ślęk, $W$ kręgu Klio i Kalliope. Staropolska epika historyczna, Wrocław-Warszawa-Kraków-Gdańsk 1973, s. 6).

5 J. Długosz, Annales seu cronicae incliti Regni Poloniae [dalej: Annales] lib. 1-2, editionem curavit et introductionem scripsit I. Dąbrowski, Varsaviae 1964, s. 51; F. Kallimach, Historia de rege Vladislao, ed. I. Lichońska, commentariis historicis illustravit T. Kowalewski, in linguam Polonam traduxit A. Komornicka, Varsaviae 1961, s. 14-15; M. Stryjkowski, O poczatkach, wywodach, dzielnościach, sprawach rycerskich i domowych sławnego narodu litewskiego, żemojdzkiego i ruskiego, przedtym nigdy od żadnego ani kruszone, ani opisane, z natchnienia Bożego a uprzejmie pilnego doświadczenia, oprac. J. Radziszewska, Warszawa 1978, s. 33, 38.

${ }^{6}$ Kroniki, czy szerzej: utwory historiograficzne, były przeznaczone dla określonego grona odbiorców, tj. osób interesujących się daną tematyką, wyposażonych w odpowiednie umiejętności intelektualne związane z trudem lektury (P. Bering, Struktury narracyjne w późnośredniowiecznych tacińskich kronikach regionalnych, Gniezno 2001, s. 44). 
ideologiczno-propagandową, tj. kształtować poczucie tożsamości czy wspólnoty członków danej zbiorowości ${ }^{7}$, ale także kreować pożądany wizerunek państwa na zewnątrz. Dla właściwej realizacji powyższych zadań ważne było odpowiednie przygotowanie merytoryczne twórców kronik. W większości przypadków zaliczali się oni do grona polskiej elity intelektualnej, często pełnili ważne funkcje w administracji państwowej czy kościelnej. Z racji posiadanego wykształcenia, wiedzy i umiejętności były to osoby najbardziej predestynowane do wypowiadania się o przeszłości, jak również do świadomego konstruowania czy modelowania pamięci o pewnych zdarzeniach zgodnie w wymogami aktualnej sytuacji bądź bieżącymi potrzebami. Przyjęty przedział czasowy jest wystarczający do prześledzenia procesu przekształcania się pamięci komunikatywnej (pokoleniowej, rodzinnej) w pamięć kulturową czyli pamięć zbiorową utrwaloną na piśmie.

Badania nad pamięcią o bitwie pod Warną należy rozpocząć od dwóch XV-wiecznych relacji, tj. stosownego fragmentu Roczników Jana Długosza oraz utworu historiograficznego Historia de rege Vladislao pióra Włocha Filipa Buonaccorsiego, występującego pod przydomkiem Kallimach ${ }^{9}$. Tradycja warneńska utrwalona na kartach tych dzieł stanowiła podstawę i punkt odniesienia dla rozważań prowadzonych w kolejnym stuleciu ${ }^{10}$. W obu źródłach tematyka związana z bitwą została ukazana w sposób wyczerpujący; opowieść o tym wydarzeniu jest rozbudowana, bogata

${ }^{7}$ B. Szacka, Czas przeszły, pamięć, mit, Warszawa 2006, s. 48-54.

${ }^{8}$ Wyodrębnienie rodzajów pamięci za: J. Assmann, Kultura pamięci [w:] Pamięć zbiorowa i kulturowa. Wspótczesna perspektywa niemiecka, red. M. Saryusz-Wo1s ka, Kraków 2009, s. 59-99. Zob. też: A. Er11, Kultura pamięci. Wprowadzenie, Warszawa 2018, s. 227-228.

9 J. Długosz, Annales, lib. 11-12, consilium ed. C. Baczkowski et al., Varsaviae 2001; F. Kallimach, Historia. Nawiązania do bitwy pod Warną można odnaleźć także w innych dziełach Włocha (Ad Innocentum VIII de bello Turcis inferendo oratio, recensuit in linguam Polonam traduxit I. Lichońska, commentariis historicis illustravit T. Kowalewski, Varsaviae 1964; De his quae a Venetis tentata sunt Persis ac Tartaris contra Turcos movendis, commentariis historicis illustravit T. Kowalewski, recensuit in linguam Polonam traduxit M. Cytowska, Varsaviae 1962; Vita et mores Gregorii Sanocei, ed., commentariis historicis illustravit, recensuit in linguam Polonam traduxit I. Lichońska, Varsaviae 1963).

${ }^{10}$ Przedmiotem zainteresowania artykułu będzie pamięć o Warnie zawarta na kartach następujących dzieł: Maciej z Miechowa, Chronica Polonorum, Cracoviae 1521; I.L. Decii, Contenta De Vetustatibus Polonorum Liber I. De Iagellonum Familia Liber II. De Sigismundi Regis Temporibus Liber III, Cracoviae 1521; Bernard Wapowski, Dzieje Korony Polskiej i WKL od roku 1380 do 1535 przez Bernarda z Rachtamowic Wapowskiego, t. 2, wyd. Mikołaj Malinow ski, Wilno 1847; Marcin Bielski, Kronika wsztkyego swyata, Kraków 1551, Marcin Kromer, De origine et rebus gestis Polonorum libri XXX, Basileae 1555; Aleksander Gwagnin, Kronika Sarmacyey Europskiey... przez Marcina Paszkowskiego za staraniem Autorowym z Lacinskiego na Polskie przełożona, Kraków 1611; Stanisław Sarnicki, Annales sive de originis et rebus gestis Polonorum er Litvanorum libri octo, b.m.w. 1587; M. Stryjkowski, O poczatkach; idem, Która przedtym nigdy światta nie widziała. Kronika Polska Litewska, Żmodzka, y wszystkiey Rusi Kijowskiey, Moskiewskiey, Siwierskiey, Wotyńskiey, Podolskiey, Podgorskiey, Podlaskiey, etc. Y rozmaite przypadki woienne y domowe, Pruskich, Mazowieckich, Pomorskich y innych Królestwu Polskiemu y Wielkiemu Księstwu Litewskiemu przyległy..., Królewiec 1582; Kronika polska Marcina Bielskiego nowo przez Joachima Bielskiego syna jego wydana, Kraków 1597; Andrzej Lubieniecki, Poloneutychia, oprac. A. Linda, M. Maciejewska, J. Tazbir, Z. Zawadzki, Warszawa-Lódź 1982. 
w szczegóły. Jan Długosz dążył do upamiętnienia dawnych dziejów Polski i ich bohaterów, jednak Roczniki nie stały się historią oficjalną i jako takie nie wzbudziły większego zainteresowania dworu królewskiego ${ }^{11}$. Inaczej było w przypadku utworu Kallimacha, Historii króla Władysława. Zadedykowana Kazimierzowi Jagiellończykowi miała służyć monarsze, kształtując i propagując pozytywny wizerunek jego osoby i całego domu Jagiellonów ${ }^{12}$. Dzieło to mogło jednocześnie spełniać jeszcze jedną istotną funkcję. Na samym początku autor, wskazując źródło inspiracji do podjęcia pracy nad dziejami Warneńczyka, odwołał się do osoby zmarłego królewicza Kazimierza (1458-1484). Młodzieniec ten w trakcie rozmowy z biskupem włocławskim Piotrem z Bnina na temat chlubnej przeszłości swego rodu miał popaść w szczególną zadumę nad losami stryja Władysława w czasie rządów tegoż na Węgrzech. Zarówno duchowny, jak i młody dynasta doszli do wniosku, że historia króla Polski i Węgier jest godna opisania ${ }^{13}$. Kallimach rozpoczął swój wywód od przywołania pamięci o dwóch reprezentantach dynastii jagiellońskiej, którzy osiągnęli (Warneńczyk) lub aspirowali do osiągnięcia (królewicz Kazimierz) Korony Świętego Stefana. Niewykluczone, że zabieg ten miał subtelnie przypominać o prawach Jagiellonów do tronu węgierskiego oraz podkreślać nieodległą tradycję związków między dwoma państwami ${ }^{14}$.

Zarówno Długosz, jak i Buonaccorsi, opisując kampanię Władysława Warneńczyka z 1444 roku, wykorzystali informacje przekazane w liście bezpośredniego świadka opisywanych zdarzeń Andrzeja de Palatio do kardynała Ludwika tytułu św. Wawrzyńca w Damaszku, datowanym na maj 1445 roku $^{15}$. Zakres wykorzystania listu był bardzo duży. Do tekstu Roczników wprowadzono całe jego fragmenty, przeplatane krótszymi lub dłuższymi uzupełnieniami dziejopisa ${ }^{16}$. W tekście Andrzeja de Palatio próżno szukać pewnych informacji, które później pojawiły się w Rocznikach,

${ }^{11}$ S. Cynarski, Uwagi nad problemem recepcji „Historii” Jana Dlugosza w Polsce XVI i XVII wieku [w:] Dlugossiana. Studia historyczne w pięćsetlecie śmierci Jana Dtugosza, red. S. Gawęda, Warszawa 1980, s. 283.

12 J. Garbacik, Kallimach jako dyplomata i polityk, Kraków 1948, s. 36; J. Nikodem, Dlugosz i Kallimach o koronie węgierskiej Wtadystawa III, „Balcanica Posnaniensia. Acta et studia” 1997, t. 8, s. 151; L. Du be1, Kallimach - włoski realizm polityczny w Polsce, „Zeszyty Naukowe Puławskiej Szkoły Wyższej” 2002, z. 4, s. 16. Apogeum zabiegów Włocha o rozpowszechnienie pożądanego wizerunku króla Kazimierza jako obrońcy chrześcijaństwa była mowa do papieża Innocentego VIII. Kallimach dowodził w niej, że Turków może pokonać jedynie król Polski.

${ }^{13}$ Kallimach, Historia, s. 14-15.

${ }^{14}$ Na początku IV 1490 r., w dwa miesiące po śmierci Macieja Korwina, w czasie obrad sejmu elekcyjnego posłowie polscy wystąpili z propozycją kandydatury młodszego syna Kazimierza Jagiellończyka - Jana Olbrachta - do objęcia tronu Węgier. Przedstawiciele strony polskiej wskazywali tam na tradycję ścisłej współpracy polsko-węgierskiej, zwłaszcza na unie personalne, jakie łączyły dwa kraje za panowania Ludwika Węgierskiego i Władysława Warneńczyka (K. B aczkowski, Walka o Węgry w latach 1490-1492. Z dziejów rywalizacji habsbursko-jagiellońskiej w basenie środkowego Dunaju, „Zeszyty Naukowe UJ. Prace Historyczne” 1995, z. 116, s. 56).

${ }^{15}$ A. Proch aska, List Andrzeja de Palatio o klęsce warneńskiej, Lwów 1882, s. 1-37. O pozostałych źródłach wykorzystanych przez kanonika krakowskiego do odtworzenia wydarzeń 1444 r. zob. Rozbiór krytyczny Annalium Poloniae Jana Dlugosza z lat 1385-1444, T. 1, opr. St. Gawęda, K. Pieradzka, J. Radzi szews ka, K. Sta chows ka, Wrocław-Warszawa-Kraków 1961, s. 332-342.

16 Wykaz zapożyczeń Długosza z omawianego listu zob. A. Prochaska, List, passim; Rozbiór krytyczny, s. 337-342. 
tj. przekazu o podjęciu przez opuszczonego przez Węgrów króla walki z Turkami i śmierci monarchy, odpowiedzi, jaką władca miał udzielić Janowi Hunyadyemu namawiającemu go do ucieczki z pola walki, czy napiętnowaniu wojewody i panów węgierskich za opuszczenie króla ${ }^{17}$. Dodatkiem Długosza jest też rozdział, w którym sformułowano zarzut pod adresem Władysława, jakoby klęska stanowiła karę Bożą za grzechy władcy ${ }^{18}$, fragment o ograbieniu ze złota i morderstwie dokonanym przez pewnego Wołocha na osobie kardynała Juliana Cesariniego ${ }^{19}$ oraz wykaz poległych i ocalałych Polaków ${ }^{20}$.

Kluczowy element przekazów o wydarzeniach roku 1444 stanowiła kwestia złamania przez stronę chrześcijańską postanowień traktatu szegedyńskiego ${ }^{21}$, co dało bezpośredni asumpt do wznowienia wojny z Turcją $\mathrm{i}-\mathrm{w}$ efekcie - doprowadziło do bitwy pod Warną. Zarówno Długosz, jak i Kallimach jednoznacznie stwierdzili, iż król sprzeniewierzył się danemu publicznie słowu. O ile kanonik krakowski pisał ogólnie o złożonej przez króla publicznej przysiędze ${ }^{22}$, to Kallimach rozbudował ten wątek. W obu przekazach położono szczególny nacisk na zakończone sukcesem starania Juliana Cesariniego o odciągnięcie panującego od dotrzymania warunków pokoju. Koronnym argumentem purpurata na rzecz nieważności przysięgi miał być fakt, że przymierze z niewiernymi zostało zawarte bez zgody Stolicy Apostolskiej. Pozwoliło to kardynałowi unieważnić je w imieniu papieża ${ }^{23}$. Tym, co łączy przekazy obu autorów, jest również wskazanie związku między przeniewierstwem króla a późniejszą klęską strony chrześcijańskiej ${ }^{24}$. Pamięć o złamaniu przysięgi przez monarchę przy czynnym współudziale przedstawiciela Stolicy Apostolskiej była bardzo trwała, pojawiała się w utworach historiograficznych powstających w XVI wieku ${ }^{25}$. Zdarzało się, że wątek ten był nieznacznie uzupełniany o nowe szczegóły. Począwszy od

17 Annales, lib. 11-12, s. 324-325, 326; List, s. 33, przyp. 4, s. 34, przyp. 6.

18 Annales, lib. 11-12, s. 327-328; List, s. 35, przyp. 8.

19 Annales, lib. 11-12, s. 328; List, s. 36, przyp. 1.

${ }^{20}$ Annales, lib. 11-12, s. 329; List, s. 36, przyp. 3.

${ }^{21}$ Wiadomości o zawarciu węgiersko-tureckiego traktatu pokojowego potwierdzonego przysięgą, a następnie o złamaniu danego słowa pod naciskiem perswazji legata papieskiego, Juliana Cesariniego, przekazuje wiele źródeł współczesnych omawianym wydarzeniom. Ich wykaz zob. J. Dąbrow ski, Rok 1444. Spór o traktat szegedyński, Wrocław-Warszawa-Kraków 1966, s. 48-51.

${ }^{22}$ Annales, lib. 11-12, s. 301.

${ }^{23}$ Ibidem, s. 306; Kallimach, Historia, s. 176-183. Oprócz wymienionego purpurata wśród osób, które nakłaniały króla do wypowiedzenia traktatu, Długosz wskazał także Jana Hunyadyego oraz Mikołaja Lasockiego, bliskiego współpracownika monarchy (Annales, lib. 11-12, s. 305-306, 311-312).

${ }_{24}$ Annales, lib. 11-12, s. 306, 311-312; Kallimach, Historia, 176-183. U Kallimacha kwestia dotrzymywania przysięgi złożonej niewiernym pozostaje niejednoznaczna. Uwidoczniło się to w opisie rozterek, jakie miały targać wojewodą Wladem Drakulem. Wołoch był związany przymierzem z Turcją i wahał się, czy w obliczu przygotowywanej drugiej wyprawy Władysława, wbrew danemu słowu, nie przyłączyć się do wojsk królewskich. Kallimach włożył w usta wojewody stwierdzenie, że sława uzyskana w czasie działań wojennych jest ceniona wyżej niż dotrzymywanie obietnicy danej niewiernym. Ostatecznie tym, co powstrzymało wojewodę od udziału w wyprawie, miała być przepowiednia pewnej Bułgarki, wieszczącej klęskę królowi Węgier (Kallimach, Historia, s. 190-193).

${ }^{25} \mathrm{O}$ uroczystej przysiędze królewskiej i uznaniu jej za nieważną przez wysłannika papieskiego w sposób lapidarny pisali: Maciej z Miechowa (Chronica Polonorum, k. CCCV), Marcin Bielski (Kronika, s. 241r.), Marcin Kromer (De origine, s. 479). 
Bernarda Wapowskiego, nadwornego historiografa króla Zygmunta Starego ${ }^{26}$, w polskim piśmiennictwie historycznym zaczęła utrwalać się tradycja mowy wygłoszonej przez Murada do jego żołnierzy. Sułtan ogłosił, „że Boga chrześcijan Jezusa, przez którego Władysław krzywo przysięgał, na pomoc wezwie i wkrótce ujrzy spełnioną nad nim karę wiarołomstwa"27. Powyższe stwierdzenie, odwołujące się do kategorii fatum ciążącego nad armią chrześcijańską, w pewien sposób racjonalizowało klęskę wojsk Władysława.

Duży wpływ na sposób przedstawiania motywu krzywoprzysięstwa króla wywarły poglądy głoszone od początku XV wieku przez przedstawicieli Akademii Krakowskiej. Paweł Włodkowic w ogłoszonym w 1415 roku traktacie Saevientibus (Traktat o władzy papieża i cesarza nad niewiernymi) potępiał nawracanie niewiernych za pomocą miecza, zakładał możliwość pokojowego współistnienia państw chrześcijańskich z pogańskimi oraz dowodził, że na gruncie prawa chrześcijański termin „bliźni” odnosi się bez różnicy zarówno do wiernych, jak i niewiernych ${ }^{28}$. Pod pojęciem tym Włodkowic rozumiał Saracenów, Żydów, innowierców oraz pogan ${ }^{29}$. W ujęciu Włodkowica wyznacznikiem relacji między państwami miały być takie wartości jak dobra wiara stron, wzajemna uczciwość czy czyste intencje ${ }^{30}$, niezależnie od religii wyznawanej przez podmioty stosunków międzynarodowych. Przytoczone przez polskiego prawnika argumenty, wykorzystane w Konstancji przez dyplomację Władysława Jagiełły na potrzeby sporu polsko-krzyżackiego, równie dobrze można było zastosować w odniesieniu do muzułmańskich sąsiadów monarchii jagiellońskiej, tj. Tatarów i Turków ${ }^{31}$, co też czyniono. Potwierdzenie stanowi ustęp z wydanej w 1521 roku kroniki Jodoka Ludwika Decjusza. Przeświadczenie o konieczności dotrzymywania

${ }^{26}$ Wapowski, autor kroniki, która obejmowała historię Polski od czasów najdawniejszych do 1535 r., w części odnoszącej się do dziejów sprzed 1480 r. opierał się na rękopisach Roczników Długosza (J. Smołucha, Bernard Wapowski - kontynuator Jana Dlugosza i ojciec polskiej kartografii [w:] Krakowskie środowisko historyczne XV-XX wieku. Ludzie-idee-dzieła, red. T. Gąsowski, J. S mołu ch a, Kraków 2018, s. 190). Wapowski zaczerpnął informację o rzekomej mowie Murada z listu datowanego z Perugii 24 VI 1445 r., którego autorstwo przypisuje się uznanemu za zwolennika husytyzmu Ambrożemu z Moraw (A.F. Grabski, Wiersze o klęsce warneńskiej. Z dziejów okolicznościowej poezji politycznej w Polsce XV w., „Prace Polonistyczne” 1967, seria 23, s. 38; J. Tazb ir, , Krzywoprzysiężca” Władysław w opinii potomnych, „Kwartalnik Historyczny” 1985, r. 92, nr 3, s. 513).

${ }^{27}$ B. Wapowski, Dzieje, s. 494. Ten sam motyw pojawił się u Aleksandra Gwagnina w polskim tłumaczeniu jego kroniki dokonanym przez: Marcina P a s zk o w sk ki e g o: „Wzgardzili Gaurowie Bogiem swym, wezmę go ja sobie przeciwko im na pomoc" (Kronika, s. 102), Stanisława S arnickie go (Annales, s. 354), Macieja Stryjkowskiego, (O poczatkach, s. 441, Kronika, k. 603), Marcina Bielskiego w wydaniu dokonanym przez jego syna (Kronika polska Marcina Bielskiego, s. 376-377, 379), Andrzeja Lubienieckiego (Poloneutychia, s. 28).

${ }^{28}$ P. Włodkowic, Saevientibus [w:] L. Ehrlich, Pisma wybrane Pawła Włodkowica, t. 1, Works of Paul Wladimiri (a Selection), Warszawa 1968, s. 1-98.

${ }^{29}$ T. Jasudowicz, Człowiek, jego prawa $i$ obowiazki w nauczaniu Pawła Włodkowica. Uwagi wstępne, „Toruński Rocznik Praw Człowieka i Pokoju” 1993, z. 1, s. 136.

${ }^{30} \mathrm{~S}$. Wielgus, Teoria ius gentium w średniowiecznej Polsce. Geneza, historia, twórcy, oryginalność, główne problemy [w:] Pawet Włodkowic i polska szkoła prawa międzynarodowego, Warszawa 2018, s. 220.

${ }^{31}$ D. Kołodziejczyk, Stosunki dawnej Rzeczypospolitej z Turcja i Tatarami: czy naprawde byliśmy przedmurzem Europy?, „Praktyka Teoretyczna” 2017, nr 4(26), s. 22. 
słowa danego wyznawcom islamu można odnaleźć w odpowiedzi, jakiej król Zygmunt i panowie polscy udzielili w 1510 roku Achillesowi de Grassis, posłowi papieża Juliusza II. Blisko związany z kancelarią i dworem królewskim kronikarz ${ }^{32}$ utrzymywał, że papieska propozycja uwikłania Polski w wojnę z Imperium Osmańskim spotkała się ze zdecydowaną odmową panującego i jego doradców. Dowodzili oni, że działania wojenne przeciwko Wysokiej Porcie nie byłyby korzystne dla Królestwa Polskiego, a nade wszystko doprowadziłyby do złamania przyrzeczenia pokoju danego wcześniej sułtanowi, a tym samym pogwałcenia prawa międzynarodowego (quod iampridem Thurcarum imperator Sarmatis pacis iuramentum transmiserat, contra ius gentium esse uisum si Poloni etiam ethnico principi fidem violarent $\left.{ }^{33}\right)$. W ten sam sposób (contra ius gentium violatum) autor ocenił fakt odstąpienia od pokoju z Turcją przez Warneńczyka ${ }^{34}$. Przyjmuje się, że poglądy Pawła Włodkowica były znane nie tylko kronikarzom bardziej mu współczesnym, ale budziły także zainteresowanie historyków z późniejszego stulecia (np. Marcina Kromera) ${ }^{35}$, przyczyniając się do podtrzymania i ugruntowania krytycznej oceny postępku chrześcijańskiego króla wobec niewiernych.

Porażka opuszczonego przez Boga wojska Władysława stanowiła w opinii wielu dziejopisarzy karę za złamanie pokoju z Turkami i grzech krzywoprzysięstwa króla, nakłonionego do tego kroku przez jego doradców. Tłumaczenie takowe nie było wytworem historiografii polskiej, jego geneza jest znacznie wcześniejsza i sięga okresu tuż po dotarciu do opinii publicznej w Europie informacji o klęsce warneńskiej. Jedną z pierwszych osób, która rozpowszechniała pogląd o związku między przegraną pod Warną a przeniewierstwem Jagiellończyka, był Eneasz Sylwiusz Piccolomini ${ }^{36}$. Jego opinia została następnie podchwycona i przekazana przez historiografię węgierską, czeską i polską ${ }^{37}$. Trwałość tej części pamięci o Warnie wiązała się z kilkoma czyn-

32 Decjusz pośredniczył przy zawieraniu małżeństwa Zygmunta Starego z Boną, a od 1520 r. pełnił funkcję sekretarza króla i jego doradcy w sprawach finansowych (A. Hirschberg, O życiu i pismach Justa Ludwika Decjusza. 1485-1545, Lwów 1874, s. 11-18; J.L. Decjusz, Księga o czasach Króla Zygmunta, przygotował do druku, wstępem i przypisami opatrzył T. Bieńkowski, tłum. zespół Koła Naukowego Studentów Filologii Klasycznej UW, Warszawa 1960, s. 6).

33 I.L. Decii, Contenta, s. LXXIII = J.L. Decjusz, Księga o czasach Króla Zygmunta, s. 49-50.

34 I.L. Decii, Contenta [...] De Iagellonum Familia Liber II, s. XLII.

35 S. Bełch, Pawet Włodkowic jako historyk i jego wplyw na Długosza [w:] Pawel Włodkowic i polska szkoła, s. 76-115; S. Wi elgu s, op. cit., s. 199.

${ }^{36}$ Powiązanie klęski pod Warną z krzywoprzysięstwem strony chrześcijańskiej zostało wyartykułowane m.in. w jego listach (jesień 1445 r.) do Zbigniewa Oleśnickiego i Leonarda, biskupa Passawy (Enee Silvii Piccolominei epistolarium seculare complectens De duobus amantibus, De naturis equorum, De curialium miseriis, post R. Wolkan iterum recognouit edidit A. van Heck, Città del Vaticano 2007, nr 179, s. 456-457, nr 192, s. 487-488). Więcej na temat zapatrywań Piccolominiego na omawianą kwestię zob.: A.F. Grabski, Wiersze, s. 31, 37; J. Tazbir, „Krzywoprzysiężca”, s. 512-513; R. Oj rzyński, Obraz Polski i Polaków w pismach Eneasza Sylwiusza Piccolominiego (papieża Piusa II), Warszawa 2014, s. 77-93.

$37 \mathrm{Na}$ ziemiach polskich najwcześniejszym znanym śladem powiązania porażki chrześcijan z karą za złamanie przysięgi jest wiersz Ego Wladislaus, datowany na lata 1445-1447 (J. Nowak-Dłużewski, Okolicznościowa poezja polityczna w Polsce. Średniowiecze, Warszawa 1963, s. 77-78; A.F. Grabski, Wiersze, s. 33-47). O kształtowaniu się pamięci o bitwie warneńskiej w Czechach i na Węgrzech 
nikami. Po pierwsze, odwołanie się do czynnika nadprzyrodzonego, „karzącej ręki” Boga, było najbardziej naturalnym i jednocześnie najłatwiejszym sposobem wyjaśnienia przyczyn niepowodzenia kampanii 1444 roku, zwłaszcza w kontekście przysięgi na Ewangelię złożonej przez króla w trakcie zatwierdzania pokoju. W okresie późnego średniowiecza krzywoprzysięstwo traktowano jako ciężką zbrodnię, skutkującą konkretnymi sankcjami prawnymi, zaś w powszechnym odczuciu bezpośrednią karą miały być nieszczęścia sprowadzone przez rozgniewanego Boga ${ }^{38}$. Po drugie, eksponowanie wątku związanego w wiarołomstwem monarchy dostarczało pouczającego przykładu o niedopuszczalności działań nagannych etycznie i moralnie, ale mogących przynieść korzyści państwu i wspólnocie ${ }^{39}$. Przykład tragicznych skutków krzywoprzysięstwa Warneńczyka miał zostać przywołany przez panów polskich jako ostrzeżenie dla króla-elekta Henryka Walezjusza, aby baczył na dotrzymanie przysięgi złożonej przy okazji zatwierdzenia praw i przywilejów jego nowej monarchii (,y przypominając mu to iako Pan Bóg srodze o krzywoprzysięstwo każdego każe, y dawali mu na przykład króla Władysława, który u Warny przez krzywoprzysięstwo zginął" ${ }^{40}$. Podobną funkcję podkreślającą konieczność dotrzymania pokoju z Turcją spełniało przywoływanie pamięci o Warnie w kronice opisującej bezkrólewia po śmierci Zygmunta Augusta i ucieczce Henryka Walezego ${ }^{41}$.

Wiarołomstwo monarchy miało być skutkiem zabiegów kardynała Juliana Cesariniego, co począwszy od Długosza, chętnie eksponowano na kartach kolejnych dzieł historiograficznych ${ }^{42}$. Ten postępek przedstawiciela Stolicy Apostolskiej został szczególnie surowo oceniony przez twórców związanych ze stronnictwem antykurialnym w łonie Kościoła katolickiego, a od XVI wieku - także przez zwolenników reformacji. Do grona tych pierwszych należy zaliczyć Kallimacha ${ }^{43}$, który uznawał Cesariniego za osobę powszechnie znienawidzoną właśnie z powodu swego udziału w nakłanianiu monarchy do złamania przysięgi ${ }^{44}$. Co więcej, wysłannik papieża, zaślepiony dążeniem do kontynuowania wojny, nie widział niczego zdrożnego w żądaniach posłów tureckich, aby Władysław przysięgał na Eucharystię. Dopiero po rzekomej stanowczej interwencji Grzegorza z Sanoka przeciw temu świętokradztwu,

zob.: A.F. Grabski, Polska w opiniach Europy Zachodniej XIV-XV w., Warszawa 1968, s. 430-435; J. Grygiel, Echa bitwy warneńskiej w historiografii czeskiej XV i XVI wieku [w:] Świat chrześcijański, s. $131-140$.

${ }^{38}$ P. Rogowski, Przysięga w średniowiecznym prawie polskim, Lublin 2016, s. 204. Wątek „niemiłego Bogu” krzywoprzysięstwa i kary w postaci pogromu wojsk chrześcijańskich został mocno wyeksponowany u Kallimacha (Historia, s. 208-209).

39 J. Tazbir, „Krzywoprzysiężca”, s. 512.

${ }^{40}$ Kronika polska Marcina Bielskiego, s. 708.

${ }^{41}$ Ś. Orzelski, Interregni Poloniae libros 1572-1576, wyd. E. Kuntze, Cracoviae 1917, s. 434, $438,443$.

${ }^{42}$ K. Janicki, Vitae regum Polonorum, Cracoviae 1573, b.p.; S. Sarnicki, Annales, s. 352; M. Kromer, De origine, s. 479; M. Stryjkowski, Kronika, s. 600-601; M. Bielski, Kronika wsztkyego swyata, s. 241 r.; Kronika polska Marcina Bielskiego, s. 375-376.

${ }^{43} \mathrm{O}$ wkładzie Kallimacha w szerzenie poglądów na temat wyższości soboru nad papieżem zob. J. Nikodem, op. cit., s. 162.

${ }^{44}$ Kallimach, Historia, s. 208-209. 
król ostatecznie zaprzysiągł pokój na Ewangelię ${ }^{45}$. Czynny udział kardynała w unieważnieniu pokoju z Turkami oraz natychmiastowa kara Boża, jaka spadła na wiarołomców, stanowiły doskonały materiał dla pisarzy związanych z reformacją. Przykładem mogą być opinie na temat przyczyn i skutków klęski warneńskiej sformułowane przez arianina Andrzeja Lubienieckiego w Poloneutychii (początek XVII w.). Duchowni doradcy króla zostali tu określeni mianem „w rozgrzeszeniu omylnych” (to o legacie papieskim), zaś największą winą króla było to, że „w radach swych księżej słuchał, którzy go do krzywoprzysięstwa przywiedli, i potem tej wojny przegrania przyczyną byli”" ${ }^{\prime \prime}$. Autor wskazywał jednocześnie, że działania te doprowadziły do przedwczesnej śmierci młodego, budzącego duże nadzieje na przyszłość monarchy (,[...] mógł ten pan, do lat dalszych przyszedłszy, wszytkiemu krześcijaństwu być bardzo pomocny" ${ }^{\prime 7}$ ). W tej i podobnych wypowiedziach przywoływanie pamięci o Warnie służyło krytykom papiestwa jako idealne narzędzie, za pomocą którego można było piętnować postępowanie kleru katolickiego, nadmiernie angażującego się w sprawy doczesne nieprzystające duchowieństwu (tj. prowadzenie wojny). Negowanie prawa papieża do zwalniania z przysięgi danej niewiernym wynikało z obaw przedstawicieli nurtów reformowanych co do uznawania przez Kościół katolicki pokojów religijnych, których byli stroną ${ }^{48}$. Podkreślanie roli doradców duchownych w sprzeniewierzeniu się przez monarchę chrześcijańskiego dobrowolnie złożonej przysiędze miało stanowić dowód na omylność dostojników kościelnych nie tylko w kwestiach doktrynalnych, ale przede wszystkim politycznych.

W oparciu o przekazy kolejnych kronik można też prześledzić kształtowanie się pamięci o Polakach biorących udział w bitwie warneńskiej ${ }^{49}$. Tradycja ta została inaczej przedstawiona przez Jana Długosza, a inaczej przez Filipa Buonaccorsiego. Dla kanonika krakowskiego opis tej konkretnej bitwy stał się doskonałą okazją do budowania pamięci o bohaterstwie rodaków, dobrze wpisywał się w propagowany przez dziejopisa patriotyzm. W jednym z ustępów Długosz zaznaczał, że niewielu Polaków uszło z życiem, ponieważ, co powtarza za listem Andrzeja de Palatio, pro more suo de fuga sua numquam cogitaverunt et quod bellicosum sit genus hominum ${ }^{50}$. Taka postawa została wyraźnie przeciwstawiona reakcji przedstawicieli innych nacji,

${ }^{45}$ Ibidem, s. 170-173.

${ }^{46}$ A. Lubieniecki, Poloneutychia, s. 26-27. Autor za wspólny mianownik niepowodzenia bitew pod Warną i Mohaczem uznawał fakt powierzenia dowództwa w nich duchownym (ibidem, s. 28).

47 Ibidem, s. 27.

48 J. Tazbir, „Krzywoprzysiężca”, s. 515.

${ }^{49}$ Współcześnie toczą się spory o liczbę Polaków, którzy wzięli udział w bitwie pod Warną. Dane szacunkowe oscylują między około pięcioma lub sześcioma tysiącami Polaków (Z. Pentek, Polscy uczestnicy wyprawy warneńskiej, „Balcanica Posnaniensia. Acta et studia” 1997, t. 8, s. 106) a trzystuosobowym oddziałem rycerzy nadwornych (W. Bukowski, Apostazja Mikołaja Lipnickiego. Przyczynek do losów „Warneńczyków” (ze spuścizny Antoniego Prochaski) [w:] Historia vero testis temporum. Księga jubileuszowa poświęcona Profesorowi Krzysztofowi Baczkowskiemu w 70. rocznicę urodzin, red. J. S mołucha, A. Waśk o, T. Graff, P.F. Nowakow ski, Kraków 2008, s. 365-368).

${ }_{50}$ Annales, lib. 11-12, s. 329. Andrzej de Palatio pisał z kolei: Polonorum vero militum nullus evasit, eo quod de fuga nunquam cogitaverunt, et bellicosissimus genus est hominum (List, s. 36). 
przede wszystkim salwującym się ucieczką z pola walki Węgrom czy Wołochom ${ }^{51}$. W zamierzeniu Długosza Polacy mieli zostać zapamiętani jako dobrzy chrześcijanie i wierni rycerze do końca wypełniający obowiązek wobec współwyznawców i władcy. Kronikarz przekazał również imiona znaczniejszych osobistości z Polski obecnych na polach warneńskich. Wśród osób, które poniosły śmierć pod Warną, wymienił braci Jana Starszego i Jana Gratusa Tarnowskich oraz synów Zawiszy Czarnego: Marcina $^{52}$ i Stanisława z Rożnowa ${ }^{53}$. Trudno wyjaśnić, dlaczego akurat te cztery osoby zostały uznane za godne upamiętnienia na kartach Roczników, skoro dziejopis dysponował informacjami na temat śmierci co najmniej kilku innych rycerzy ${ }^{54}$. Być może w przypadku Zawiszyców, synów bohatera spod Golubaca (filii olim optime memorie Nigri Zawische) $)^{55}$, chodziło o ukazanie szerszego niż Warna kontekstu walk chrześcijan z niewiernymi oraz przypomnienie zasług Polaków w tym względzie. Wśród uczestników, którzy ocaleli z pogromu warneńskiego, wymienił Długosz Jana Rzeszowskiego, Grzegorza z Sanoka, Pawła z Grabowa, Wojciecha z Żychlina, Jana Wątróbkę, Andrzeja z Sienna, Jana z Borowna, Marcina Chorążyca i Piotra z Latoszyna ${ }^{56}$. Ponadto ocaleli także obecni pod Warną Mikołaj Lasocki, kanclerz Jan Koniecpolski i podkanclerzy Piotr Woda. Nie zostali oni wskazani w tym miejscu, pojawiają się jednak na kartach Roczników później. Wydaje się, że wymienieni byli w większości osobami, z którymi kronikarz miał styczność z racji sprawowanych funkcji kościelnych czy swej działalności dyplomatycznej, co pozwalało na bezpośrednie pozyskanie informacji ${ }^{57}$. Mielibyśmy więc $\mathrm{w}$ tym przypadku do czynienia z przenikaniem pamięci indywidualnej na karty dzieła historiograficznego. Pisząc o ocalałych, większość XVI-wiecznych kronikarzy wspominała jedynie Grzegorza z Sanoka i Jana Rzeszowskiego. Wyjątkiem był Marcin Kromer ${ }^{58}$, który - za Dłu-

${ }^{51}$ Annales, lib. 11-12, s. 325-326.

${ }_{52}$ Wbrew twierdzeniu Długosza Marcin powrócił spod Warny do kraju, gdzie zmarł po $1447 \mathrm{r}$. (B. Możejko, S. Szybkowski, B. Śliwiński, Zawisza Czarny z Garbowa herbu Sulima, Gdańsk 2003, s. 46). Niewykluczone, że z powodu zgonu Zawiszyca około trzech lat po bitwie pod Warną kronikarz nie odnotował faktu jego szczęśliwego powrotu do Polski.

53 Annales, lib. 11-12, s. 329.

${ }^{54} \mathrm{~W}$ kalendarzu katedry krakowskiej pod datą 1444 r. pojawiła się zapiska sporządzona ręką Długosza, w której wśród poległych pod Warną oprócz Jana Starszego Tarnowskiego i Marcina Zawiszyca wymieniono Spytka Jarosławskiego, Pawła Wojnickiego ze Sienna, Dziersława Włostowskiego i Jana Pleszowskiego (Kalendarz katedry krakowskiej [w:] Pomniki Dziejowe Polski, seria II, t. V, wyd. Z. Kozłowska-Budkowa, Warszawa 1978, s. 184).

55 Annales, lib. 11-12, s. 329.

${ }^{56}$ Ibidem, s. 329.

${ }^{57}$ Raczej nie ma co do tego wątpliwości w przypadku: Grzegorza z Sanoka, Jana Rzeszowskiego, Wojciecha z Żychlina, Jana Wątróbki czy Marcina Chorążyca z Wrocimowic, z którymi stykał się w trakcie swej służby kościelnej i państwowej. Z kolei informacje o udziale Piotra z Latoszyna w kampanii warneńskiej kronikarz mógł pozyskać, jeżeli nie od samego Piotra, to od jego brata Jana, rektora uniwersytetu krakowskiego. Wiadomo, że Długosz i Jan uczestniczyli razem w poselstwie polskim na sejm węgierski w VIII 1475 r. (L. Hajdukiewicz, Jan z Latoszyna, https://www.ipsb.nina. gov.pl/a/biografia/jan-z-latoszyna, dostęp: 18 X 2019 r.).

${ }_{58}$ Maciej z Miechowa, Chronica, k. CCCVII; A. Gwagnin, Kronika, s. 103; B. Wapowski, Dzieje, s. 515; S. Sarnicki, Annales, s. 354; A. Lubieniecki, Poloneutychia, s. 27; M. Bielski, Kronika, s. 241. Za Długoszem wszystkich ocalałych wymienił M. Kromer (De origine, s. 483). 
goszem - wymienił także pozostałych rycerzy, którym udało się przeżyć. Niektórzy przywoływali również imiona tych, którzy zginęli pod Warną 59 .

Kallimach w Historii króla Władysława skupił się na przedstawieniu dokonań właściwie dwóch Polaków, tj. Grzegorza z Sanoka i Leszka Bobrzyckiego. Protektor Buonaccorsiego został ukazany jako jeden z najważniejszych doradców króla, któremu ten wręcz zawdzięczał przeforsowanie wyjazdu Jagiellończyka na Węgry ${ }^{60}$. Ponadto w ujęciu Kallimacha Grzegorz swą mądrością oraz przenikliwością miał zdecydowanie wyróżniać się wśród innych duchownych obecnych przy monarsze ${ }^{61}$. Chociaż, jak zostało to wskazane powyżej, obecność Grzegorza w czasie bitwy warneńskiej została odnotowana przez XVI-wiecznych kronikarzy, to jednak nie utrzymało się twierdzenie o znaczeniu przyszłego arcybiskupa lwowskiego jako wpływowego doradcy Warneńczyka. Z kolei wśród najdzielniejszych Polaków walczących u boku Władysława miał wyróżnić się Leszek Bobrzycki - dziadek boskiej Fanii-Swentochy, opiewanej w wierszach lwowskiej muzy poety ${ }^{62}$. Rzekomy przodek kochanki Kallimacha urósł na kartach jego dzieła do rangi jednego z najważniejszych dowódców bitwy, który znalazł bohaterską śmierć u boku monarchy. Tymczasem wzmianek o Bobrzyckim - w kontekście bitwy pod Warną - próżno szukać w innych źródłach powstałych przed czasami Buonaccorsiego. Warto na chwilę zatrzymać się przy przywołanym przykładzie, niezwykle frapującym z punktu widzenia rozważań o kształtowaniu „pamięci warneńskiej”. Istnieją różne poglądy na temat autentyczności postaci Leszka Bobrzyckiego; część badaczy sądzi, że jest to postać fikcyjna ${ }^{63}$. Niezależnie jednak od tego, czy uznamy jego istnienie za fakt historyczny, czy za wymysł Włocha, nie ulega wątpliwości, że rola przypisywana Bobrzyckiemu w kampanii warneńskiej została wykreowana przez XV-wiecznego historyka. Celem tego zabiegu było albo upamiętnienie czy wręcz wprowadzenie do historii antenata muzy poety (przy założeniu, że Leszek rzeczywiście istniał), albo dążenie Buonaccorsiego do nobilitacji rodu Swentochy poprzez wskazanie na pokrewieństwo z rycerzem. Nie ulega natomiast wątpliwości, że przekazana przez Kallimacha pamięć o Leszku Bobrzyckim weszła do tradycji, stając się często powielanym składnikiem przekazów późniejszych kronikarzy o Warnie ${ }^{64}$.

${ }_{59}$ M. Kromer, De origine, s. 482-483; M. Stryjk ow ski, Kronika, s. 607; Kronika polska Marcina Bielskiego, s. 380-381.

${ }^{60}$ Kallimach, Historia, s. 40-41.

${ }^{61}$ Pogląd o znaczeniu Grzegorza jako wpływowej persony wśród piastujących wysokie stanowiska państwowe nie utrzymał się w literaturze przedmiotu (T. Graff, Grzegorz z Sanoka jako arcybiskup lwowski [w:] 600-lecie urodzin Grzegorza z Sanoka. Studia o Grzegorzu z Sanoka i jego czasach, red. L. Puchała, S.A. Sroka, Sanok 2008, s. 61).

${ }^{62}$ Kallimach, Historia, s. 42.

${ }^{63}$ Zdecydowanie przeciwko autentyczności Bobrzyckiego wypowiadał się Jarosław Nikodem, który uznał postać rycerza za twór wyobraźni Kallimacha (J. Ni k o d e m, op. cit., s. 163). Większość współczesnych historyków, odrzucając informacje o tak wielkiej roli przypisywanej przez Buonaccorsiego Bobrzyckiemu, dopuszcza możliwość uczestniczenia tej osoby w bitwie warneńskiej (E. P o tk o w s ki, Warna 1444, Warszawa 2004, s. 170; M. Bie1ski, Władystaw Warneńczyk, s. 98, 106, 133; A. Foryt, op. cit., s. 266).

${ }^{64}$ M. Kromer, De origine, s. 482; S. Sarnicki, Annales, s. 353; M. Stryjkowski, Kronika, s. 606; Kronika polska Marcina Bielskiego, s. 379; A. Lubieniecki, Poloneutychia, s. 27. 
XVI-wieczni historycy piszący o Polakach biorących udział w bitwie warneńskiej powtarzali informacje zawarte $\mathrm{w}$ dziełach poprzedników, przede wszystkim u Długosza i Kallimacha. Rzadko można spotkać się z sytuacją, gdy do późniejszej relacji dodawano coś nowego. Tym bardziej na uwagę zasługuje tradycja o pięciu rycerzach, którzy zginęli pod Warną, przekazana przez Spominki przeworskie. Autor zapiski wymienił wśród poległych Jana Tarnowskiego starszego, Zawiszę Czarnego, Włoszowskiego, Hynka Balickiego i Żegotę młodszego ${ }^{65}$. Zapiska została sporządzona najprawdopodobniej po 1480 roku, jako że informacja o bitwie pojawiła się po omówieniu hołdu złożonego przez wojewodę mołdawskiego Stefana królowi Kazimierzowi Jagiellończykowi w tym roku ${ }^{66}$. Przyjmuje się, że omawiane źródło powstało najprawdopodobniej w klasztorze Bożogrobców w Przeworsku. Dużo miejsca poświęcono tu pochwałom głoszonym pod adresem Leliwitów, fundatorów i darczyńców klasztoru ${ }^{67}$. Niewątpliwie autor tej narracji upamiętnił tradycję rodzinną założycieli zgromadzenia przeworskiego. Wymienienie w gronie poległych Zawiszy Czarnego można tłumaczyć w dwojaki sposób. Mogło to być spowodowane zatarciem pamięci o rzeczywistym miejscu zgonu rycerza bądź ewentualną pomyłką pisarza. Niewykluczone jednak, że umieszczenie w tym zestawieniu Zawiszy było zabiegiem celowym. Być może w świadomości zbiorowej końca XV wieku pamięć o Warnie była o wiele żywsza niż o bitwie pod Golubacem. Wpisanie Zawiszy Czarnego w kontekst warneński utrwalało pamięć o rycerzu ${ }^{68}$.

Wyjątkiem w przywoływaniu wiadomości o uczestnikach bitwy z 1444 roku była też kronika Bernarda Wapowskiego. Jej autor, pisząc o ocaleniu Jana Rzeszowskiego, wspominał, że był on wujem jego ojca, „w pierwszej utarczce ranny i na wozie królewskim złożony". Dziejopis dodał także ustęp o misji, jaką Władysław zlecił swojemu dworzaninowi, Piotrowi Wapowskiemu. Miał on zostać wysłany do Polski, by zrekrutować na potrzeby wojny 2000 ludzi. Piotr wypełnił swe zadanie, lecz w trakcie podróży powrotnej na Węgry doszła do niego wiadomość o klęsce wojsk chrześcijańskich. Zabawił wraz z prowadzonym oddziałem kilka dni nad Cisą, po czym powrócił do kraju ${ }^{69}$. Wspomniany Piotr, podobnie jak Jan Rzeszowski, był krewnym kronikarza, a historię tę Bernard musiał znać z przekazów rodzinnych. Odwoływanie się do pamięci rodzinnej przy konstruowaniu narracji o polskich uczestnikach kampanii 1444 roku pojawia się też w Mowie o wojnie tureckiej Stanisława

${ }^{65}$ Spominki przeworskie [w:] Monumenta Poloniae Historica [dalej: MPH], t. 3, wyd. A. Bielowski, Lwów 1878, s. 275.

${ }^{66} \mathrm{~W}$. Michalski, Rodzinne dzieje z nieodległej przeszłości w pamięci polskich familii rycerskich [w:] Przeszłość w kulturze średniowiecznej Polski, cz. 1: Przeszłość obrazowana w tradycjach zapisanych $i$ ujęciach historiograficznych, red. J. Banaszkiewicz, A. Dąbrówka, P. Węcowski, Warszawa 2018, s. 155-156.

${ }^{67}$ Spominiki przeworskie, s. 272-272; S. Lew, Karty z dziejów szkolnictwa i kultury Przeworska [w:] Siedem wieków Przeworska. Szkice, studia, materiaty z dziejów miasta, red. A. Kunyszyn, Rzeszów 1974, s. 182.

${ }^{68}$ Wyjaśnienie tej kwestii będzie możliwe po prześledzeniu procesu kształtowania się i funkcjonowania pamięci o śmierci Zawiszy Czarnego na kartach polskich źródeł narracyjnych w XV wieku i w stuleciach następnych.

${ }^{69}$ B. Wapowski, Dzieje, s. 515. 
Orzechowskiego. Autor przywołuje tutaj tradycję rodzinną, wedle której jego dziad Aleksander wraz z towarzyszami z powiatu przemyskiego udał się na „wojnę warneńską", później zaś - jako jedyny ocalały z prowadzonego przez siebie oddziału - dzielił się refleksjami bitewnymi z członkami własnej rodziny ${ }^{70}$. Przykłady te poświadczają istnienie i podtrzymywanie tradycji rodzinnej o udziale przodków w zmaganiach pod Warną. Przyjmuje się, że ten typ pamięci o wielkich wydarzeniach był niezwykle żywy i bogaty w szczegóły w kolejnych dwóch bądź trzech pokoleniach $^{71}$. Prawidłowość ta znajduje potwierdzenie w przywołanych powyżej przypadkach, gdy autorzy powoływali się na wiadomości przekazywane przez ich dziadków. Elementy pamięci rodzinnej, przenikając do dzieł historiograficznych, ożywiały oraz wzbogacały narrację o wydarzeniach z roku 1444.

Odrębne miejsce w rozważaniach XV- i XVI-wiecznych kronikarzy o bitwie pod Warną zajmuje pamięć o królu Władysławie III ${ }^{72}$. Zarówno Długosz, jak i Kallimach pozostawili obszerną charakterystykę młodego monarchy. Generalnie działania panującego w kontekście bitwy warneńskiej zostały ocenione pozytywnie. Podkreślano jego waleczność i bohaterstwo, zaangażowanie w walkę w obronie wiary katolickiej, przedkładanie honoru nad własne życie, wierność wobec towarzyszy walki ${ }^{73}$, ale także dbałość o bezpieczeństwo ludności cywilnej ${ }^{74}$. Ten pozytywny obraz monarchy uległ pewnemu zniekształceniu w jednym z ustępów Roczników Długosza. Poszukując przyczyn doznanej klęski wojsk chrześcijańskich, dziejopis wskazywał na zemstę Boga za doznaną obrazę, a nade wszystko za złamanie złożonej Mu przysięgi. Obraza Boskiego Majestatu miała być spowodowana skrajnie niemoralnym prowadzeniem się króla (in marium libidinem proclivus) oraz uleganiem przez młodego władcę nieczystym i wstrętnym rozkoszom (incestus et abhominabiles voluptates). Kronikarz tłumaczył, jakoby w czasie kampanii wojennej przeciwko Turcji w 1443 roku monarcha stojąc w obliczu przeważających sił wroga, złożył uroczystą przysięgę, że zmieni swe postępowanie. Przysięgę król złamał już w trakcie powrotu $\mathrm{z}$ wyprawy, ponownie popełniając bezbożną zbrodnię (scelus nefandum $)^{75}$. Powyższe

70 S. Orzechowski, Mowy, wyd. K.J. Turowski, Sanok 1855, s. 71. Krótko o tradycji warneńskiej w rodzinie Orzechowskiego zob. M. Bębenek, Polskie sny o wskrzeszeniu „Christianitatis” [w:] Stanisław Orzechowski - pisarz polityczny, red. J. Musiał, Przemyśl-Kraków 2014, s. 36.

${ }^{71}$ W. Michalski, op. cit., s. 161.

${ }^{72}$ Problematyka związana z oceną króla Władysława pojawia się w kilku studiach. Wśród nich warto wymienić: O. Halecki, Spór o Warneńczyka, „Teki Historyczne” 1958, t. 9 (zwłaszcza s. 1618, 33-34); A.F. Grabski, Wiersze, s. 25-64; J. Śliziński, Legenda wokót postaci Warneńczyka, „Pamiętnik Słowiański” 1973, t. 23, s. 303-315 (autor w sposób bardzo skondensowany przedstawił kształtowanie się legendy króla na przestrzeni dziejów); J. Tazbir, „Krzywoprzysiężca”, s. 511-532; J. Krochmal, Władysław Warneńczyk w świetle Roczników Jana Dlugosza, „Balcanica Posnaniensia. Acta et studia" 1997, t. 8, s. 129-143; P. Szw e d o, Sub banderio cruciatae - Władystaw III Jagiellończyk jako średniowieczny rycerz idealny. Wizerunek władcy na podstawie Roczników Jana Dlugosza, „Średniowiecze Polskie i Powszechne” 2017, t. 9(13), s. 186-210.

${ }^{73}$ Honor oraz wierność wobec współwalczących stanowiły dwie główne wartości etosu rycerskiego propagowanego w epoce staropolskiej. Więcej na ten temat zob. M. Janicki, Pochówki i pamięć polegtych (XIV-XVII w.), „Napis” 2001, seria VII, s. 58 i n.

${ }_{74}$ Annales, lib. 11-12, s. 313-330; Kallima ch, Historia, s. 204-209.

${ }^{75}$ Annales, lib. 11-12, s. 327-328. 
słowa, które skłaniają część współczesnych do wygłaszania opinii o homoseksualizmie króla ${ }^{76}$, stanowią jeden z bardziej zagadkowych fragmentów narracji o Władysławie i po dzień dzisiejszy budzą konsternację uczonych. Jest to tym bardziej zastanawiające, że dalej w Rocznikach pojawia się wręcz hagiograficzna charakterystyka panującego, gdzie nazwano go najznamienitszym wojownikiem w obronie wiary i władcą świętym ${ }^{77}$. Dlatego niektórzy badacze wypowiadają się przeciwko autorstwu Długosza i optują za możliwością późniejszego wstawienia tekstu szkalującego króla $^{78}$. Najczęściej przywoływanymi argumentami jest brak omawianego passusu w części rękopisów Roczników ${ }^{79}$ oraz wskazana powyżej niespójność w charakterystyce króla. Wydaje się jednak, że drugi z argumentów nie jest zbyt przekonujący, jeżeli weźmiemy pod uwagę manierę pisarską stosowaną przez dziejopisa, zwłaszcza sytuacjonizm $\mathrm{w}$ formowanych przezeń ocenach wydarzeń czy bohaterów ${ }^{80}$. Warto również zwrócić uwagę na konstrukcję całego fragmentu. Jego autor podjął próbę wyjaśnienia przyczyn klęski pod Warną. W pierwszej kolejności wskazywał na karę, jaka spotkała lud chrześcijański za grzechy popełnione przeciwko Bogu motyw często przywoływany w piśmiennictwie doby średniowiecza przy racjonalizowaniu porażek, jakich doznawali wierni z rąk barbarzyńców ${ }^{81}$. Dopiero po tym stwierdzeniu pojawiło się napiętnowanie zachowania oraz oskarżenie panującego o krzywoprzysięstwo, jako dodatkowa przyczyna klęski warneńskiej. Równie istotne pozostają słowa poprzedzające opis zachowania władcy. Pojawia się tutaj wyraźne stwierdzenie, że niektórzy w oparciu o najbliższe prawdy przypuszczenia twierdzą (asserunt tamen nonnulli ex coniecturis verissimilibus), iż Władysław był głównym

76 Więcej na ten temat zob. u: J. Tazbir, „Krzywoprzysieżca”, s. 514, 527; S. Sroka, op. cit., s. 120-121; A. Foryt, op. cit., s. 317.

77 Annales, lib. 11-12, s. 330.

${ }^{78}$ Przegląd dawniejszej literatury odnośnie autorstwa Długosza zob. Rozbiór krytyczny, s. 341. Tezę o napisaniu tego fragmentu przez Długosza podważa J. Niko dem, op. cit., s. 156.

${ }^{79}$ Kwestię tę wyjaśnił Piotr Dymmel (Tradycja rękopiśmienna Roczników Jana Dlugosza, Warszawa 1992, s. 194-195).

${ }^{80} \mathrm{Z}$ podobną sytuacją możemy się spotkać przy ocenie panowania Władysława Jagiełły sformułowanej przez Długosza. Opinie na temat ojca Warneńczyka były bardzo niejednoznaczne, kronikarz przechodził od pochwał, często bardzo oszczędnych, do niemalże potępienia pewnych działań czy decyzji monarchy (więcej zob.: J. Skomiał, Jan Dlugosz o Władystawie II Jagielle. Charakterystyka króla w świetle Annales seu Cronicae incliti Regni Poloniae, „Acta Universitatis Lodziensis. Folia Iuridica” 1994, t. 61, s. 15-31; A. Talarowski, Od poganina do króla arcychrześcijańskiego. Wizerunek Wtadysława Jagielty w Rocznikach Jana Dlugosza, „Średniowiecze Polskie i Powszechne” 2017, t. 9(13), s. 127-152; A. Ob ara-Pawłow ska, Stanowisko Jana Dlugosza wobec cudzoziemskich władców na tronie polskim, „Średniowiecze Polskie i Powszechne” 2019, nr 11(15), s. 135-140). Równie krytycznie dziejopis wypowiadał się o Kazimierzu Jagiellończyku. Przyjmuje się, że Długosz nie cenił przedstawicieli dynastii jagiellońskiej - obcych władców na tronie polskim.

${ }^{81}$ K. DeVries, God and Defeat in Medieval Warfare: Some Preliminary Thoughts [w:] The Circle of War in the Middle Ages. Essays on Medieval Military and Naval History, eds. D.J. Kag ay, L.J.A. Villalon, Woodbridge 1999, s. 87-97; A. Teterycz-Puzio, Wojownik, obrońca wiary $i$ uciśnionych? Wzorce rycerskie $w$ świetle średniowiecznych przekazów narracyjnych [w:] Ethos rycerski w kulturze. Tradycje i kontynuacje. T. I: W kręgu średniowiecza, red. T. Banaś-Korniak, B. Stuchlik-Surowiak, Katowice 2017, s. 159. 
sprawcą porażki warneńskiej ${ }^{82}$. Powyższe bardzo wymowne słowa, z którymi autor nie utożsamia się wprost, mogą sugerować nawiązanie do opinii formułowanych i artykułowanych m.in. przez Piccolominiego, wskazujących na odpowiedzialność monarchy za klęskę ${ }^{83}$. Z kolei przypisanie królowi skłonności do nienazwanych, grzesznych praktyk seksualnych miało lepiej uzasadniać porażkę chrześcijan ${ }^{84}$. Ten przekaz Długosza nie był powielany w późniejszych utworach historiograficznych. Być może wiązało się to $\mathrm{z}$ faktem częstych interwencji cenzorskich i dworskich, którym poddawane były kroniki powstające w XVI stuleciu ${ }^{85}$. Tak poważne oskarżenia natury moralnej i religijnej pod adresem króla były nie do przyjęcia z punktu widzenia dynastii panującej ${ }^{86}$. XVI-wieczni kronikarze przywoływali za to obraz króla-wojownika dzielnie walczącego z janczarami, który ostatecznie wolał ponieść śmierć z ręki wroga, niż uciec z pola bitwy ${ }^{87}$. Władysława pamiętano jako najlepszego (optimus) władcę, którego zachowaniu nie można niczego zarzucić (morum honestate preclarissimus ${ }^{88}$, „młodzieńca odważnego i wspaniałego umysłu”, po Aleksandrze Witoldzie największego w rodzie Giedymina ${ }^{89}$, najszlachetniejszego ${ }^{90}$, miłosiernego i nabożnego ${ }^{91}$. Chociaż dziejopisowie wypowiadali się w ten sposób o całokształcie panowania króla Władysława, to było ono oceniane głównie przez pryzmat jego walki na polach warneńskich.

Przywoływanie przez historiografię XV i XVI wieku pamięci o bitwie pod Warną wiązało się także z kreowaniem wizerunku panujących z dynastii jagiellońskiej jako obrońców chrześcijaństwa w starciu z Turkami. Stosunek polskich elit intelektualnych i politycznych do zagrożenia tureckiego był dosyć ambiwalentny. Z jednej strony, począwszy od Kallimacha, w piśmiennictwie coraz mocniej akcentowano konieczność podjęcia krucjaty antytureckiej, z czym wiąże się m.in. fenomen tzw. turcyków, czyli literatury antytureckiej ${ }^{92}$. Z drugiej zaś strony po nieszczęśliwej wy-

${ }^{82}$ Annales, lib. 11-12, s. 327.

${ }_{83}$ Zob. przyp. 36.

${ }^{84}$ Więcej na temat sposobu postrzegania i znaczenia seksualności władców polskich na kartach dzieła kanonika krakowskiego zob. A. Obara-Pawłows k a, Polish Monarchs'Sexuality in the Light of the Annals by Jan Dlugosz, „Res Historica” 2021, t. 51, s. 103-143.

${ }^{85}$ M. Michalski, Przekazy o chrzcie księcia Mieszka w piśmiennictwie polskim od schytku średniowiecza po połowę wieku XIX, „Kronika Miasta Poznania” 2016, nr 1, s. 64.

${ }^{86}$ P. Dymme1, op. cit., s. 195.

${ }^{87}$ Maciej z Miechowa, Chronica, k. 306-307; B. Wapowski, Dzieje, s. 505; M. Kromer, De origine, s. 481; M. Stryjkowski, Kronika, s. 605-606; M. Bielski, Kronika wsztkyego swyata, s. $241 \mathrm{v}$.

${ }^{88}$ Maciej z Miechowa, Chronica, k. 307; podobnie: I.L. Decii, Contenta [...] De Iagellonum Familia Liber II, s. XLII; M. Kromer, De origine, s. 483.

${ }^{89}$ B. Wapowski, Kronika, s. 516-517.

${ }_{90}$ S. Sarnicki, Annales, s. 355.

${ }_{91}$ Kronika polska Marcina Bielskiego, s. 382. Pobożność Władysława podkreślał też autor Spominek bochnieńskich (w: MPH 3, wyd. S. Lukas, s. 244).

${ }_{92}$ Za początek polskiej literatury antytureckiej uznaje się zachowaną w odpisach mowę wygłoszoną przez Mikołaja Lasockiego, dziekana kapituły krakowskiej, do papieża Mikołaja V 9 XII 1448 r. (P. Ta fiło w sk i, ,Imago Turci”. Studia z dziejów komunikacji społecznej w dawnej Polsce (1453-1572), Lublin 2013, s. 146-147; tam też inne przykłady turcyków). Więcej na temat literatury antytureckiej 
prawie bukowińskiej króla Jana Olbrachta w 1497 roku oraz po poddaniu Węgier panowaniu tureckiemu w 1529 roku działania dyplomacji polskiej zmierzały w kierunku pokojowego ułożenia relacji z państwem tureckim ${ }^{93}$. Ich efektem było zawarcie w 1533 roku bezprecedensowego i bardzo trwałego, jak się miało okazać, pokoju między Polską a Turcją. Nie dziwi więc, że wątku antytureckiego nie podejmowali w swoich utworach literackich twórcy związani z dworem królewskim, doskonale zorientowani w meandrach polityki Rzeczypospolitej wobec muzułmańskiego sąsiada ${ }^{94}$. Niezależnie od przyjętej optyki w literaturze XV-XVI wieku można odnaleźć ślady potwierdzające przekonanie o nadzwyczajnej roli Polski, która miała bronić Europy przed barbarzyńcami. Wiąże się ono z pojawiającym się w piśmiennictwie omawianego okresu motywem „przedmurza chrześcijaństwa” - antemurale christianitatis $^{95}$. Na gruncie polskim został on rozpowszechniony przez Filipa Buonaccorsiego, który w liście do papieża Innocentego VIII wskazywał, że państwo polskie po wstąpieniu na tron Władysława Jagiełły zaczęło ochraniać resztę Europy przed niszczycielskimi najazdami Tatarów ${ }^{96}$. Sam motyw akcentowania zasług Władysława Warneńczyka dla obrony chrześcijaństwa pojawił się już wcześniej u Długosza. Niekonsekwentny w ocenie młodego władcy kronikarz uznał Władysława za najznamienitszego wojownika walczącego o wiarę katolicką ${ }^{97}$. Z kolei Kallimach jako przyczynę powołania Władysława na tron węgierski wskazywał przekonanie

w Polsce zob. J. Nosowski, Polska literatura polemiczno-antyislamistyczna XVI, XVII i XVIII w., z. 1, Warszawa 1974. Kallimach uchodził na dworze krakowskim za specjaliste od spraw tureckich (F. Bujak, Kallimach i znajomość państwa tureckiego w Polsce ok. poczatku XVI w., „,Rozprawy Akademii Umiejętności. Wydział Historyczno-Filozoficzny" 1901, seria II, t. 15, s. 275-276; J. Garbacik, Ze studiów nad polska polityka zagraniczna na przetomie XV i XVI w. w'świetle nowo odkrytych źródel w Zagrzebiu [w:] Dziesięciolecie Wyższej Szkoty Pedagogicznej w Krakowie, Kraków 1957, s. 350-357). Buonaccorsi, oprócz wypraw do Turcji podejmowanych w ramach działalności dyplomatycznej na dworze polskim, został zapamiętany jako autor Mowy do papieża Innocentego VIII, w której nawoływał do zawarcia sojuszu między papiestwem a Królestwem Polskim w celu pokonania potęgi tureckiej.

${ }^{93}$ A. Dziubiński, Stosunki dyplomatyczne polsko-tureckie $w$ latach 1500-1572 w kontekście międzynarodowym, Wrocław 2005, passim. Pełny wykaz i omówienie traktatów pokojowych zawieranych, począwszy od XV do początku XVII stulecia, między Polską a Turcją zob. D. Kołodziejczyk, Ottoman-Polish Diplomatic Relations (15 th $18^{\text {th }}$ Century). An Annotated Edition of Ahdnames and Other Documents, Leiden-Boston-Köln 2000, s. 99-128).

${ }^{94}$ A. Wyczański, Między kultura a polityka. Sekretarze królewscy Zygmunta Starego (1506-1548), Warszawa 1990, s. 186.

${ }^{95}$ Więcej o idei Królestwa Polskiego jako przedmurza chrześcijaństwa zob.: J. Tazbir, Polska przedmurzem Europy, Warszawa 2004; idem, Od antemurale do przedmurza, dzieje terminu, „Odrodzenie i Reformacja w Polsce" 1984, t. 29, s. 166-184 = From Antemurale to Przedmurze, the History of the Term, „Odrodzenie i Reformacja w Polsce” 2017, t. 61, s. 67-87; W. Weintrau b, Renaissance Poland and Antemurale Christianitatis, „Harvard Ukrainian Studies” 1979-1980, vol. 3-4, no. 2, s. 920-930; P. Srodecki, Wtadystaw III and the Polish-Hungarian Bulwark topoi against the Background of the Ottoman Threat in the $15^{\text {th }}$ Century [w:] Hungaro-Polonica. Young Scholars on Medieval PolishHungarian Relations, eds. D. Bagi, G. Barabás, Z. Máté, Pécs 2016, s. 327-356; K. Niemczyk, Antemurale Christianitatis? Propaganda antyturecka a wyprawa Jana Olbrachta w 1497 roku w świetle źródet, „Zeszyty Naukowe Uniwersytetu Jagiellońskiego. Prace Historyczne” 2019, nr 146, z. 1, s. 43-61.

${ }_{96} \mathrm{Kallimach,} \mathrm{Ad} \mathrm{Inocentium} \mathrm{VIII,} \mathrm{s.} \mathrm{59;} \mathrm{idem,} \mathrm{De} \mathrm{his} \mathrm{quae,} \mathrm{s.} 53$.

${ }^{97}$ Annales, lib. 11-12, s. 330. 
Madziarów o tym, że będzie on w stanie ochronić ich królestwo. Przy podejmowaniu decyzji o powierzeniu korony Jagiellończykowi Węgrzy mieli na uwadze dokonania jego ojca, który zasłynął w walce z Tatarami ${ }^{98}$. Narracja ta była zgodna z przekazem płynącym $\mathrm{z}$ oficjalnych deklaracji Władysława formułowanych $\mathrm{w}$ trakcie jego zabiegów o uzyskanie Korony Świętego Stefana ${ }^{99}$. Zasługą Kallimacha pozostaje też wyeksponowanie i spopularyzowanie przekonania o znaczącej roli całej dynastii jagiellońskiej w dziele obrony chrześcijaństwa. Ród Jagiellonów został przyrównany do św. Pawła. Dzięki nawróceniu i wybraniu przez Boga zostali oni przeznaczeni do tego, aby osłaniać religię chrześcijańską przed grożącym jej niebezpieczeństwem ${ }^{100}$.

Tradycja o Władysławie III, który poświęcił własne życie pod Warną, stanowiła ważny element identyfikacji domu jagiellońskiego i była chętnie wykorzystywana przez historiografię za czasów Kazimierza Jagiellończyka ${ }^{101}$. Przywoływanie pamięci o bitwie warneńskiej po upadku Konstantynopola w 1453 roku niosło ze sobą określone przesłanie polityczne, bardzo pożądane z punktu widzenia dyplomacji Jagiellonów. Traumatyczne doświadczenie przejścia Konstantynopola pod panowanie tureckie pozwalało bardziej docenić podejmowane przez Władysława próby pokonania państwa osmańskiego, a niewykluczone, że także wyparcia Turków z tej części Europy. Artykułowana u części współczesnych potrzeba (re)interpretacji kampanii warneńskiej pojawiła się w cytowanym wielokrotnie w literaturze fragmencie listu kardynała Zbigniewa Oleśnickiego do Eneasza Sylwiusza Piccolominiego. Pismo to było odpowiedzią na list Włocha z 1451 roku $^{102}$. Purpurat, odnosząc się do wcześniejszych negatywnych, a wręcz kłamliwych sądów formułowanych przez Sieneńczyka na temat osoby zmarłego króla oraz kampanii warneńskiej, bronił dobrego imienia Władysława III oraz reprezentowanej przez monarchę idei współdziałania chrześcijańskiej Europy w walce ze wspólnym wrogiem. Bardzo znamienne pozostają zwłaszcza słowa: Non sua ille temeritate, ut aliquibus asserere placuit, sed scelere nostro victus est, qui illum et in custodiendo stricto fefellimus et in administrando bello non adjuvimus, sed irrisimus ${ }^{103}$. Trudno ocenić, na ile sformułowanie

${ }^{98}$ Kallimach, Ad Innocentium VIII, s. 65; idem, De his quae, s. 53. Z kolei w Historii króla Władysława akcentowano przede wszystkim przymioty młodego króla (jego męstwo, zdolności, sławę, którą zdążył już uzyskać) oraz wskazywano, że w obliczu zagrożeń wewnętrznych i zewnętrznych związek z Polską stanowi jedyny ratunek dla Węgier (idem, Historia, s. 22-24).

99 P. Srodecki, op. cit., s. 331-337.

${ }^{100}$ Kallimach, Ad Innocentium VIII, s. 65.

${ }^{101}$ P. Srodecki, op. cit., s. 349. Oprócz Roczników Długosza i dzieł Kallimacha, z Historia króla Władysława na czele, część historyków opowiadała się za istnieniem jeszcze jednego, niezachowanego do naszych czasów utworu o powołaniu Władysława na tron węgierski i jego walce z Turkami, autorstwa Grzegorza z Sanoka. Informację o nim przekazał Buonaccorsi (Vita et mores Gregorii Sanocei, s. 62). Dawniejsi badacze przyjmowali wręcz, że piszący Historię króla Władysława Włoch w znacznej mierze bazował na rękopisie jego lwowskiego protektora (M. Wiszniew ski, Historya literatury polskiej, t. 3, Warszawa 1841, s. 469-470; M. Han dels man, Historyka, opr. P. Węc ow ski, Warszawa 2010, s. 74). Współcześni historycy odrzucają możliwość istnienia takiego dzieła (J. Nikodem, op. cit., s. 163-164).

102 J. Smołucha, Kontakty Zbigniewa z Eneaszem Sylwiuszem Piccolominim [w:] Zbigniew Oleśnicki ksiązę Kościoła i mą̇̇ stanu, red. F. Kiryk, Z. Nog a, Kraków 2006, s. 208.

${ }^{103}$ Der Briefwechsel des Eneas Silvius Piccolomini: Abt. 3: Brief als Bischof von Siena: Briefe von seiner Erhebung zum Bischof von Siena bis zum Ausgang des Regensburger Reichstages (23. September 
owo, przypisujące jakąś winę autorowi listu, wynikało z rzeczywistych wyrzutów sumienia Oleśnickiego z powodu nieudzielenia wystarczającej pomocy, a wręcz wyśmiewania ambitnych planów militarnych niedoświadczonego władcy ${ }^{104}$. Wydaje się, że biskupowi bardziej chodziło o wykazanie, że działania króla, tak mocno krytykowane m.in. przez Piccolominiego ${ }^{105}$, po upływie niespełna dziesięciu lat okazywały się przemyślane i dalekowzroczne. Los, jaki stał się udziałem Konstantynopola i jego mieszkańców, dostarczał dodatkowego argumentu dla strony polskiej w kreowaniu pozytywnego przekazu o wydarzeniach pod Warną ${ }^{106}$. Kampanię z 1444 roku przedstawiono jako zakończoną co prawda niepowodzeniem, ale ważną próbę wyparcia Turków z Europy Południowo-Wschodniej, a jednocześnie zabezpieczenia części Starego Kontynentu przed dalszą inwazją niewiernych. Dla zilustrowania takiego sposobu wykorzystywania pamięci o poległym królu warto odwołać się do dwóch mów wygłoszonych przez Erazma Ciołka przed papieżami Aleksandrem VI (1501) i Juliuszem II (1505). Postać Władysława została tam przedstawiona przez pryzmat jego walki i śmierci za wiarę katolicką ${ }^{107}$. Taka interpretacja znaczenia bitwy warneńskiej mogła okazać się pomocna dla polityki zagranicznej prowadzonej przez Jagiellonów w na przełomie XV i XVI stulecia.

Tradycja o Władysławie jako obrońcy chrześcijaństwa była powielana przez część XVI-wiecznych kronikarzy. W ujęciu Macieja Stryjkowskiego panujący był

1450-1. Juni 1454) [w:] Fontes rerum Austricarum, wyd. R. Wolk an, Bd. 68, Wien 1918, nr 137, s. 253.

104 D. Piwowarczyk, Herold Mikołaj Chrzastowski, „Rocznik Polskiego Towarzystwa Heraldycznego" 2003, t. 6, s. 19.

${ }^{105}$ W Europie tuż po 1444 r. ukształtowały się dwie sprzeczne oceny Warny. Z jednej strony można mówić o tzw. koncepcji krucjatowej, reprezentowanej przez istniejące w różnych częściach Europy środowiska związane z kurią papieską. Kampania warneńska i jej bohaterowie (Władysław, kardynał Julian Cesarini) byli chwaleni, uznawani za wzór do naśladowania, ukazywani jako męczennicy za wiarę. $Z$ drugiej zaś strony pisarze czy dyplomaci związani z opcją antykurialną interpretowali klęskę pod Warną w kategoriach kary za złamanie przysięgi oraz pogwałcenie dziedzicznych praw dynastii habsburskiej do tronu węgierskiego, zaś za sprawców tej tragedii uważano Cesariniego oraz złych doradców młodego i niedoświadczonego monarchy (A.F. Grabski, Wiersze, s. 37-40; idem, Polska w opiniach, s. 411-418). Do bardziej wpływowych twórców związanych z tym drugim nurtem należy zaliczyć poglądy wspomnianego już, szczególnie nieprzychylnego Polsce i Polakom, a związanego z dworem Habsburgów, Eneasza Sylwiusza Piccolominiego. W swoich listach pisanych w 1445 r. do różnych osobistości świeckich i kościelnych poruszał on kwestie związane z niedawną klęską wojsk chrześcijańskich. Niemniej jednak Włoch stopniowo zmienił swoją ocenę wydarzeń warneńskich oraz króla Polski i Węgier (A.F. Grabski, Polska w opiniach, s. 414-415).

${ }^{106}$ Doskonałego przykładu dostarcza mowa posła Kazimierza Jagiellończyka, Lutka z Brzezia, wygłoszona w V 1454 r. na sejmie w Ratyzbonie. Strona polska ustami swego wysłannika przekonywała, że niepowodzenie pod Warną skutkowało upadkiem Konstantynopola. Wyeksponowano również fakt udzielenia przez monarchów chrześcijańskich niewielkiej pomocy walczącemu z wrogiem krzyża Władysławowi (Codex epistolaris seculi decimi quinti, t. 1, pars 2, ed. J. Szujski, Cracoviae 1876, nr 137, s. 151).

${ }^{107}$ Erazm Ciołek w mowie do papieża Aleksandra VI wypowiedział się o królu Władysławie w następujący sposób: Hic pro sancta religione contra gentem Machometanem viriliter pugnavit, una cum Iuliano Cardinali gloriosissime occubuit, multis antea triumphis honorifice de hoste reportatis (Vetera monumenta Poloniae et Lithuaniae gentiumque finitimarum historiam illustrantia, vol. 2, ed. A. Theiner, Romae 1861, s. 279). Z kolei przed papieżem Juliuszem II Erazm podkreślał, że: Vladislaus Rex cum Turcis manum conferens pro fide Christi fuso sanguine mori voluit (ibidem, s. 301). 
nieodrodnym synem „świętej” dynastii jagiellońskiej ${ }^{108}$. Joachim Bielski wskazywał, że król prowadził wojnę, aby przysłużyć się całemu chrześcijaństwu i wypędzić Turków z Europy ${ }^{109}$. Przekazy te, sporządzane długi czas po opisywanych wydarzeniach, w odmiennych warunkach politycznych straciły swój walor propagandowy. Ich zadanie polegało bardziej na utrwalaniu pamięci o świetnej przeszłości dynastii panującej oraz przypominaniu jej zasług dla wspólnoty chrześcijańskiej.

Szukając odpowiedzi na pytanie o znaczenie pamięci o Warnie w polskich źródłach historiograficznych do końca XVI wieku, można zacytować wybitnego polskiego historyka literatury Tadeusza Ulewicza, który stwierdził: „,...] utrwalona mocno w pamięci pokoleń działała w Polsce legenda warneńska, zapładniając jeszcze i w dobie zygmuntowsko-batoriańskiej, jak dowodzą choćby zamierzenia epickie Kochanowskiego oraz urywek jego poematu o Warneńczyku. To nie epizod, jak w 1428 śmierć rycerza Zawiszy Czarnego pod Golubacem nad Dunajem, to sprawa żywa przez półtora wieku ${ }^{110}$ Rzeczywiście - kolejne pokolenia kronikarzy XVI wieku wspominały zmagania warneńskie oraz tragiczną śmierć króla Władysława. Punktem odniesienia dla ich rozważań była tradycja o bitwie i jej uczestnikach, wykształcona w źródłach historiograficznych z drugiej połowy XV wieku. Późniejsze przekazy nie wnosily wiele nowego do sfery faktograficznej, często również powtarzano sądy i opinie bezpośrednio lub pośrednio zaczerpnięte od Długosza czy Kallimacha ${ }^{111}$. Nie oznacza to jednak, że śledzenie tych relacji jest bezzasadne. Wszystkie opowieści, niezależnie od ich długości i liczby przytaczanych szczegółów, wypełniały jedno ważne zadanie, określane mianem funkcji tożsamościowej pamięci ${ }^{12}$. Postać poległego na polach warneńskich króla, walczącego w interesie całej chrześcijańskiej Europy, została przekształcona w symbol pożądanych wartości i zachowań wobec wspólnoty, za pośrednictwem których można identyfikować się z ową zbiorowością.

108 „Lecz jednak ono święte Jagiełowo plemię Własną ręką skropiło krwią Turecką ziemię

Za co mu obraz wieczny sława postawiła" (M. Stryjkow ski, Kronika, s. 606).

109 Kronika polska Marcina Bielskiego, s. 382

110 T. Ulewicz, Związi kulturalne i literackie Polski ze Stowiańszczyzna południowozachodnia w dobie humanizmu i renesansu. Kilka uwag i propozycji, „Ruch Literacki” 1963, z. 4, s. 168.

111 Janusz Tazbir stwierdził, że porównywanie kolejnych uporządkowanych chronologicznie fragmentów dzieł polskich dziejopisów z XVI wieku, prowadzi do wniosku, że przepisywali od siebie nawzajem, a poszczególne relacje różnią się między sobą liczbą przywoływanych szczegółów i objętością (J. Tazbir, ,Krzywoprzysiężca”, s. 515-516).

112 B. Szacka, op. cit., s. 48-54. 


\title{
BIBLIOGRAFIA
}

\author{
Źródła
}

Bielski M., Kronika wsztkyego swyata, Kraków 1551.

Codex epistolaris seculi decimi quinti, t. 1, pars 2, ed. J. Szujski, Cracoviae 1876.

Der Briefwechsel des Eneas Silvius Piccolomini: Abt. 3: Brief als Bischof von Siena: Briefe von seiner Erhebung zum Bischof von Siena bis zum Ausgang des Regensburger Reichstages (23. September 1450-1. Juni 1454) [w:] Fontes rerum Austricarum, wyd. R. Wolkan, Bd. 68, Wien 1918.

Decii I.L., Contenta De Vetustatibus Polonorum Liber I. De Iagellonum Familia Liber II. De Sigismundi Regis Temporibus Liber III, Cracoviae 1521.

Decjusz J.L., Księga o czasach Króla Zygmunta, przygotował do druku, wstępem i przypisami opatrzył T. Bieńk owski, tłum. zespół Koła Naukowego Studentów Filologii Klasycznej UW, Warszawa 1960.

Długos z J., Annales seu cronicae incliti Regni Poloniae, lib. 1-2, editionem curavit et introductionem scripsit I. Dąbrowski, Varsaviae 1964.

Długosz J., Annales seu cronicae incliti Regni Poloniae, lib. 11-12, consilium ed. C. B aczkowski et al., Varsaviae 2001.

Enee Silvii Piccolominei epistolarium seculare complectens De duobus amantibus, De naturis equorum, De curialium miseriis, post R. Wolkan iterum recognouit edidit A. van Heck, Città del Vaticano 2007.

Gwagnin A., Kronika Sarmacyey Europskiey... przez Marcina Paszkowskiego za staraniem Autorowym z Lacinskiego na Polskie przełożona, Kraków 1611.

Janicki K., Vitae regum Polonorum, Cracoviae 1573.

Kalendarz katedry krakowskiej [w:] Pomniki Dziejowe Polski, seria II, t. V, wyd. Z. Kozłowska-Budkowa, Warszawa 1978.

Kallimach F., Ad Innocentum VIII de bello Turcis inferendo oratio, recensuit in linguam Polonam traduxit I. Lichońska, commentariis historicis illustravit T. Kowalewski, Varsaviae 1964.

Kallimach F., De his quae a Venetis tentata sunt Persis ac Tartaris contra Turcos movendis, commentariis historicis illustravit T. Kowalewski, recensuit in linguam Polonam traduxit M. Cytowska, Varsaviae 1962.

Kallimach F., Historia de rege Vladislao, ed. I. Lichońska, commentariis historicis illustravit T. Kowalewski, in linguam Polonam traduxit A. Komornicka, Varsaviae 1961.

Kallimach F., Vita et mores Gregorii Sanocei, ed., commentariis historicis illustravit, recensuit in linguam Polonam traduxit I. Lichońska, Varsaviae 1963.

Kromer M., De origine et rebus gestis Polonorum libri XXX, Basileae 1555.

Kronika polska Marcina Bielskiego nowo przez Joachima Bielskiego syna jego wydana, Kraków 1597.

Lubieniecki A., Poloneutychia, oprac. A. Linda, M. Maciejewska, J. Tazbir, Z. Zawadzki, Warszawa-Łódź 1982.

Maciej z Miechowa, Chronica Polonorum, Cracoviae 1521.

Orzechowski S., Mowy, wyd. K.J. Turowski, Sanok 1855.

Orzelski Ś., Interregni Poloniae libros 1572-1576, wyd. E. Kuntze, Cracoviae 1917.

Sarnicki S., Annales sive de originis et rebus gestis Polonorum er Litvanorum libri octo, bmw 1587.

Spominki bochnieńskie [w:] Monumenta Poloniae Historica, t. 3, wyd. S. Lukas, Lwów 1878. 
Spominki przeworskie [w:] Monumenta Poloniae Historica, t. 3, wyd. A. Bielow ski, Lwów 1878.

Stryjkowski M., Która przedtym nigdy światta nie widziała. Kronika Polska Litewska, Żmodzka, y wszystkiey Rusi Kijowskiey, Moskiewskiey, Siwierskiey, Wotyńskiey, Podolskiey, Podgorskiey, Podlaskiey, etc. Y rozmaite przypadki woienne y domowe, Pruskich, Mazowieckich, Pomorskich y innych Królestwu Polskiemu y Wielkiemu Księstwu Litewskiemu przylegty..., Królewiec 1582.

Stryjkowski M., O początkach, wywodach, dzielnościach, sprawach rycerskich i domowych sławnego narodu litewskiego, żemojdzkiego i ruskiego, przedtym nigdy od żadnego ani kruszone, ani opisane, z natchnienia Bożego a uprzejmie pilnego doświadczenia, oprac. J. Radziszewska, Warszawa 1978.

Vetera monumenta Poloniae et Lithuaniae gentiumque finitimarum historiam illustrantia, vol. 2, ed. A. Theiner, Romae 1861.

Wapow ski B., Dzieje Korony Polskiej i WKL od roku 1380 do 1535 przez Bernarda z Rachtamowic Wapowskiego, t. 2, wyd. Mikołaj Malinowski, Wilno 1847.

Włodkowic P., Saevientibus [w:] L. Ehrlich, Pisma wybrane Pawła Włodkowica, t. 1, Works of Paul Wladimiri (a Selection), Warszawa 1968.

\section{Opracowania}

Assmann J., Kultura pamięci [w:] Pamięć zbiorowa i kulturowa. Współczesna perspektywa niemiecka, red. M. Saryusz-Wolska, Kraków 2009, s. 59-99.

Baczkowski K., Walka o Wegry w latach 1490-1492. Z dziejów rywalizacji habsbursko-jagiellońskiej w basenie środkowego Dunaju, „Zeszyty Naukowe UJ. Prace Historyczne" 1995, z. 116.

Bełch S., Paweł Włodkowic jako historyk i jego wptyw na Długosza [w:] Pawet Włodkowic i polska szkoła prawa międzynarodowego, Warszawa 2018, s. 76-115.

Bering P., Struktury narracyjne w późnośredniowiecznych łacińskich kronikach regionalnych, Gniezno 2001.

Bębenek M., Polskie sny o wskrzeszeniu „Christianitatis” [w:] Stanisław Orzechowski pisarz polityczny, red. J. Musiał, Przemyśl-Kraków 2014, s. 29-42.

Bielski M., Władysław Warneńczyk na Batkanach (1443-1444). Dwie wyprawy, Toruń 2009.

Bujak F., Kallimach i znajomość państwa tureckiego w Polsce ok. początku XVI w., „Rozprawy Akademii Umiejętności. Wydział Historyczno-Filozoficzny” 1901, seria II, t. 15, s. $268-288$.

Bukowski W., Apostazja Mikołaja Lipnickiego. Przyczynek do losów „Warneńczyków” (ze spuścizny Antoniego Prochaski) [w:] Historia vero testis temporum. Ksiega jubileuszowa poświęcona Profesorowi Krzysztofowi Baczkowskiemu w 70. rocznicę urodzin, red. J. Smołucha, A. Waśko, T. Graff, P.F. Nowakowski, Kraków 2008, s. 365-396.

Cynarski S., Uwagi nad problemem recepcji „Historii” Jana Dtugosza w Polsce XVI i VII wieku [w:] Dlugossiana. Studia historyczne w pięćsetlecie śmierci Jana Dtugosza, red. S. Gawęda, Warszawa 1980, s. 281-290.

Dąbrowski J., Rok 1444. Spór o traktat szegedyński, Wrocław-Warszawa-Kraków 1966.

DeVries K., God and Defeat in Medieval Warfare: Some Preliminary Thoughts [w:] The Circle of War in the Middle Ages. Essays on Medieval Military and Naval History, eds. D.J. Kagay, L.J.A. Villalon, Woodbridge 1999, s. 87-97.

Dubel L., Kallimach - włoski realizm polityczny w Polsce, „Zeszyty Naukowe Puławskiej Szkoły Wyższej” 2002, z. 4, s. 13-26. 
Dymmel P., Tradycja rękopiśmienna Roczników Jana Dlugosza, Warszawa 1992.

Dziubiński A., Stosunki dyplomatyczne polsko-tureckie w latach 1500-1572 w kontekście międzynarodowym, Wrocław 2005.

Er1l A., Kultura pamięci. Wprowadzenie, Warszawa 2018.

Foryt A., 1444. Krucjata polskiego króla, Kraków 2019.

Garbacik J., Kallimach jako dyplomata i polityk, Kraków 1948.

Garbacik J., Ze studiów nad polska polityka zagraniczna na przełomie XV i XVI w. w świetle nowo odkrytych źródeł w Zagrzebiu [w:] Dziesięciolecie Wyższej Szkoły Pedagogicznej w Krakowie, Kraków 1957, s. 347-362.

Grabski A.F., Polska w opiniach Europy Zachodniej XIV-XVw., Warszawa 1968.

Grabski A.F., Wiersze o klęsce warneńskiej. Z dziejów okolicznościowej poezji politycznej w Polsce $X V$ w., „Prace Polonistyczne” 1967, seria 23, s. 26-54.

Graff T., Grzegorz z Sanoka jako arcybiskup lwowski [w:] 600-lecie urodzin Grzegorza z Sanoka. Studia o Grzegorzu z Sanoka i jego czasach, red. L. Puchała, S.A. Sroka, Sanok 2008, s. 58-73.

Grygiel J., Echa bitwy warneńskiej w historiografii czeskiej XV i XVI wieku [w:] Świat chrześcijański $i$ Turcy osmańscy $w$ dobie bitwy pod Warna: pokłosie sesji zorganizowanej przez Instytut Historii Uniwersytetu Jagielleńskiego $w$ Krakowie w dniach 14-15 listopada 1994 r. w 550-lecie bitwy pod Warna, red. D. Quirini-Popławska, ,Zeszyty Naukowe Uniwersytetu Jagiellońskiego. Prace Historyczne” 1995, z. 119, s. 131-140.

Hajdukiewicz L., Jan z Latoszyna, https://www.ipsb.nina.gov.pl/a/biografia/jan-z-latoszyna.

Halecki O., Spór o Warneńczyka, „Teki Historyczne” 1958, t. 9, s. 16-34.

Handelsman M., Historyka, opr. P. Węcowski, Warszawa 2010.

Hirschberg A., O życiu i pismach Justa Ludwika Decjusza. 1485-1545, Lwów 1874.

Janicki M., Pochówki i pamięć poległych (XIV-XVII w.), „Napis” 2001, seria VII, s. 57-77.

Jasudowicz T., Człowiek, jego prawa i obowiazki w nauczaniu Pawła Włodkowica. Uwagi wstepne, „Toruński Rocznik Praw Człowieka i Pokoju” 1993, z. 1, s. 131-149.

Kołodziejczyk D., Ottoman-Polish Diplomatic Relations (15 th $-18^{\text {th }}$ Century). An Annotated Edition of 'Ahdnames and Other Documents, Leiden-Boston-Köln 2000.

Kołodziejczyk D., Stosunki dawnej Rzeczypospolitej z Turcja i Tatarami: czy naprawde byliśmy przedmurzem Europy?, „Praktyka Teoretyczna” 2017, nr 4(26), s. 16-36.

Krochmal J., Władysław Warneńczyk w świetle Roczników Jana Długosza, „Balcanica Posnaniensia. Acta et studia" 1997, t. 8, s. 129-143.

Lew S., Karty z dziejów szkolnictwa i kultury Przeworska [w:] Siedem wieków Przeworska. Szkice, studia, materiały z dziejów miasta, red. A. Kunyszyn, Rzeszów 1974, s. 163-202.

Michalski M., Przekazy o chrzcie księcia Mieszka w piśmiennictwie polskim od schytku średniowiecza po połowe wieku XIX, „Kronika Miasta Poznania” 2016, nr 1, s. 61-79.

Michalski W., Rodzinne dzieje z nieodległej przeszłości w pamięci polskich familii rycerskich [w:] Przeszłość w kulturze średniowiecznej Polski, cz. 1: Przeszłość obrazowana w tradycjach zapisanych i ujęciach historiograficznych, red. J. Banaszkiewicz, A. Dąbrówka, P. Węcowski, Warszawa 2018, s. 143-161.

Możejko B., Szybkowski S., Śliwiński B., Zawisza Czarny z Garbowa herbu Sulima, Gdańsk 2003.

Niemczyk K., Antemurale Christianitatis? Propaganda antyturecka a wyprawa Jana Olbrachta w 1497 roku w świetle źródet, ,Zeszyty Naukowe Uniwersytetu Jagiellońskiego. Prace Historyczne" 2019, nr 146, z. 1, s. 43-61.

Nikodem J., Długosz i Kallimach o koronie wegierskiej Władysława III, „Balcanica Posnaniensia. Acta et studia" 1997, t. 8, s. 145-165. 
Nosowski J., Polska literatura polemiczno-antyislamistyczna XVI, XVII i XVIII w., z. 1, Warszawa 1974.

Nowak-Dłużewski J., Okolicznościowa poezja polityczna w Polsce. Średniowiecze, Warszawa 1963.

Obara-Pawłowska A., Polish Monarchs' Sexuality in the Light of the Annals by Jan Dlugosz, „Res Historica” 2021, t. 51, s. 103-143.

Obara-Pawłow ska A., Stanowisko Jana Długosza wobec cudzoziemskich władców na tronie polskim, „Średniowiecze Polskie i Powszechne” 2019, nr 11(15), s. 119-145.

Ojrzyński R., Obraz Polski i Polaków w pismach Eneasza Sylwiusza Piccolominiego (papieża Piusa II), Warszawa 2014.

Pentek Z., Polscy uczestnicy wyprawy warneńskiej, „Balcanica Posnaniensia. Acta et studia" 1997, t. 8, s. 93-108.

Piwowarczyk D., Herold Mikołaj Chrzastowski, „Rocznik Polskiego Towarzystwa Heraldycznego" 2003, t. 6, s. 15-24.

Potkowski E., Warna 1444, Warszawa 2004.

Prochaska A., List Andrzeja de Palatio o klęsce warneńskiej, Lwów 1882.

Rogowski P., Przysięga w średniowiecznym prawie polskim, Lublin 2016.

Rozbiór krytyczny Annalium Poloniae Jana Dlugosza z lat 1385-1444, T. 1, opr. St. Gawęda, K. Pieradzka, J. Radziszewska, K. Stachowska, Wrocław-Warszawa-Kraków 1961.

Skomiał J., Jan Dlugosz o Władysławie II Jagielle. Charakterystyka króla w świetle Annales seu Cronicae incliti Regni Poloniae, „Acta Universitatis Lodziensis. Folia Iuridica” 1994, t. 61, s. 15-31.

Smołucha J., Bernard Wapowski - kontynuator Jana Dtugosza i ojciec polskiej kartografii [w:] Krakowskie środowisko historyczne XV-XX wieku. Ludzie-idee-dzieła, red. T. Gąsowski, J. Smołucha, Kraków 2018, s. 183-194.

Smołucha J., Kontakty Zbigniewa z Eneaszem Sylwiuszem Piccolominim [w:] Zbigniew Oleśnicki książę Kościoła i mąż stanu, red. F. Kiryk, Z. Noga, Kraków 2006, s. 205-210.

Srodecki P., Władysław III and the Polish-Hungarian Bulwark topoi against the Background of the Ottoman Threat in the $15^{\text {th }}$ Century [w:] Hungaro-Polonica. Young Scholars on Medieval Polish-Hungarian Relations, eds. D. Bagi. G. Barabás, Z. Máté, Pécs 2016.

Sroka S., Stawa, chwała i plotka. Władysław Warneńczyk jako król Węgier, „Przegląd Nauk Historycznych" 2016, r. 15, nr 2, s. 103-126.

Szacka B., Czas przeszły, pamięć, mit, Warszawa 2006.

Szczerbicka-Ślęk L., W kręgu Klio i Kalliope. Staropolska epika historyczna, WrocławWarszawa-Kraków-Gdańsk 1973.

Szwedo P., Sub banderio cruciatae - Władysław III Jagiellończyk jako średniowieczny rycerz idealny. Wizerunek władcy na podstawie Roczników Jana Dtugosza, „Średniowiecze Polskie i Powszechne" 2017, t. 9(13), s. 186-210.

Śliziński J., Legenda wokół postaci Warneńczyka, „Pamiętnik Słowiański” 1973, t. 23, s. 303-315.

Świat chrześcijański i Turcy osmańscy $w$ dobie bitwy pod Warną: pokłosie sesji zorganizowanej przez Instytut Historii Uniwersytetu Jagielleńskiego w Krakowie w dniach 14-15 listopada 1994 r. w 550-lecie bitwy pod Warną, red. D. Quirini-Popławska, ,Zeszyty Naukowe Uniwersytetu Jagiellońskiego. Prace Historyczne” 1995, z. 119, s. 7-160.

Tafiłowski P., ,Imago Turci”. Studia z dziejów komunikacji społecznej $w$ dawnej Polsce (1453-1572), Lublin 2013.

Talarowski A., Od poganina do króla arcychrześcijańskiego. Wizerunek Władysława Jagietly w Rocznikach Jana Dtugosza, ,Średniowiecze Polskie i Powszechne” 2017, t. 9(13), s. 127-152. 
Tazbir J., From Antemurale to Przedmurze, the History of the Term, „Odrodzenie i Reformacja w Polsce" 2017, t. 61, s. 67-87.

Tazbir J., ,Krzywoprzysiężca” Władysław w opinii potomnych, „Kwartalnik Historyczny” 1985, r. 92, nr 3, s. 511-532.

Tazbir J., Od antemurale do przedmurza, dzieje terminu, „Odrodzenie i Reformacja w Polsce" 1984 , t. 29 , s. 166-184.

Tazbir J., Polska przedmurzem Europy, Warszawa 2004.

Teterycz-Puzio A., Wojownik, obrońca wiary i uciśnionych? Wzorce rycerskie $w$ świetle średniowiecznych przekazów narracyjnych [w:] Ethos rycerski w kulturze. Tradycje $i$ kontynuacje. T. I: $W$ kręgu średniowiecza, red. T. Banaś-Korniak, B. Stuchlik-Surowiak, Katowice 2017, s. 151-183.

Ulewicz T., Związi kulturalne i literackie Polski ze Słowiańszczyzna południowozachodnia $w$ dobie humanizmu i renesansu. Kilka uwag i propozycji, „Ruch Literacki” 1963, z. 4, s. 163-181.

Warna 1444. Rzeczywistość i tradycja, „Balcanica Posnaniensia. Acta et studia” 1997, t. 8, s. 5-233.

Weintraub W., Renaissance Poland and Antemurale Christianitatis, „Harvard Ukrainian Studies" 1979-1980, vol. 3-4, no. 2, s. 920-930.

Wielgus S., Teoria ius gentium w średniowiecznej Polsce. Geneza, historia, twórcy, oryginalność, główne problemy [w:] Paweł Włodkowic i polska szkoła prawa międzynarodowego, Warszawa 2018, s. 191-232.

Wiszniewski M., Historya literatury polskiej, t. 3, Warszawa 1841.

Wyczański A., Między kulturą a polityka. Sekretarze królewscy Zygmunta Starego (15061548), Warszawa 1990. 